\title{
A narrative review of herbal preparations against RNA viruses
}

\author{
Eghbal Jasemi ${ }^{1 *}$, Saeideh Momtaz ${ }^{1,2,4 * *}$, Reza Ghaffarzadegan', Amir Hossein Abdolghaffari, $3,2,4$, \\ Mohammad Abdollahi
}

\author{
Medicinal Plants Research Center, Institute of Medicinal Plants, ACECR, Tehran, Iran. \\ ${ }^{2}$ Toxicology and Diseases Group, Pharmaceutical Sciences Research Center (PSRC), The Institute of Pharmaceutical Sciences (TIPS), and Department of Toxicology and \\ Pharmacology, School of Pharmacy, Tehran University of Medical Sciences, Tehran, Iran. \\ ${ }^{3}$ Department of Toxicology and Pharmacology, School of Pharmacy, Tehran Medical Sciences, Islamic Azad University, Tehran, Iran. \\ ${ }^{4}$ Gastrointestinal Pharmacology Interest Group, Universal Scientific Education and Research Network, Tehran, Iran. \\ * Eghbal Jasemi and Saeideh Momtaz contributed equally in this work. \\ *Correspondence to: Saeideh Momtaz (E-mail: saeideh58_momtaz@yahoo.com) \\ (Submitted: 03 January 2021 - Revised version received: 28 January 2021 - Accepted: 08 February 2021 - Published online: 26 February 2021)
}

\begin{abstract}
Objective Although several therapeutics were designed to control infectious diseases, viral infections are still fatal. Currently, evidence extracted from in vivo, in vitro, and in silico studies support the antiviral activity of many herbs scientifically; however, the therapeutic potential of many other herbs is still unknown. Plants and their products may potentially control the propagation of viruses in a variety of conditions.

Methods Data were extracted from PubMed, Scopus, Google Scholar, and Science Direct from 1983 to 2020. We gathered a list of plant extracts, phytochemicals, and herbal formulations that can inhibit RNA viral infections, mainly those are originated from the coronaviruses family. We also provided an overview of their inhibitory mechanism of actions.

Results Plant families, including Lamiaceae, Asteraceae, and Myrtaceae, contain the highest number of species with anti-coronaviruses activities, respectively.

Conclusions It can be suggested that the combination of these antiviral ingredients with each other, any synthetic compound, or already approved drugs or inhibitors can be a novel approach for antiviral therapies.

Keywords viruses, coronaviruses, herbal extracts, phytochemicals, essential oils
\end{abstract}

\section{Introduction}

Viruses are microscopic particles ranging in size from 30 to $300 \mathrm{~nm}$, lacking typical cellular structures. They are not able to reproduce outside the living host cell and are more like a large chemical compound. For this reason, they are also called compulsive intracellular parasites. Viruses can infect hosts ranging from bacteria to animals, plants to humans. ${ }^{1-3}$ Viruses rely on host cell surface receptors to enter the cell and employ host cellular machinery to replicate, assemble, and release new virus particles. Each virus has a specific mechanism to infect the host through the attachment of the virus to host cell membrane via binding of molecules of the outer surface of the virion to a receptor molecule on the host cell (protein or carbohydrate); penetration and uncoating of the virus and subsequent release of the virions into host cell; reverse transcription of viral RNA into DNA (i.e., Retroviruses); integration of the viral DNA into host cell genome; use of the cellular system for gene duplication and translation (i.e., human immunodeficiency virus (HIV)), or use of their system to produce mRNA coding for viral proteins (early genes); synthesis and assembly of nucleocapsids (late genes); release of the naked virions by cell lysis. Alternatively, viruses with envelopes can be released by a process known as budding, in which the nucleocapsid is wrapped by the membrane and pinched off ${ }^{4-8}$ (Fig. 1).

As of now, viral infections are significant threats to human and animal health, imposing a tremendous economic burden. During the past two decades, the epidemic of Ebola virus, chikungunya virus, Zika virus, Yellow fever, the severe acute respiratory syndrome (SARS) virus and the Middle East Respiratory Syndrome Coronavirus (MERS-CoV), influenza,
Nipah and henipaviral diseases, and Lassa fever raised significant challenges for public health authorities all over the world, highlighting the emerge of strategies to predict, prevent, or control the pathogens geographic spread, and the human-tohuman transmission. ${ }^{9}$ In the 21 st century, three members of the $\beta$-coronavirus genus caused deadly infections in humans. In 2002, the outbreak of SARS-CoV began in northern China and extended globally. After that, MERS-CoV spread out in the Middle East in 2012, and lately, SARS-CoV-2 (COVID-19) was reported on December 30, 2019, in Wuhan City, Hubei Province, China. SARS is an $80-160 \mathrm{~nm}$ single-stranded positive RNA virus surrounded by a coat containing the E2 virus binding protein, the E1 matrix protein, and the nucleocapsid $\mathrm{N}$ protein. To date, no proven effective therapeutics or vaccines exist for human coronaviruses infections. ${ }^{10}$

Current treatment options for coronavirus infections include medications such as Lopinavir/Ritonavir, Oseltamivir, Chloroquine, Hydroxychloroquine, Remdesivir, Favipiravir; nucleoside analogs; neuraminidase (NA) inhibitors; peptide (EK1); abidol; RNA synthesis inhibitors (such as TDF, 3TC); anti-inflammatory drugs (such as hormones and other molecules); angiotensin-converting enzyme inhibitors or angiotensin receptor blockers; and Chinese traditional medicine such ShuFengJieDu Capsules and Lianhuaqingwen Capsule. A patent review study offered that proteases inhibitors (since proteases are essential for viruses replication), monoclonal antibodies, and interferons (INFs) are definite targets for coronavirus infection treatment. This study also concluded that traditional formulations containing natural compounds might help to improve symptoms of infection such as fever, cough, sore throat, and shortness of breath. ${ }^{11,12} \mathrm{~A}$ recent 


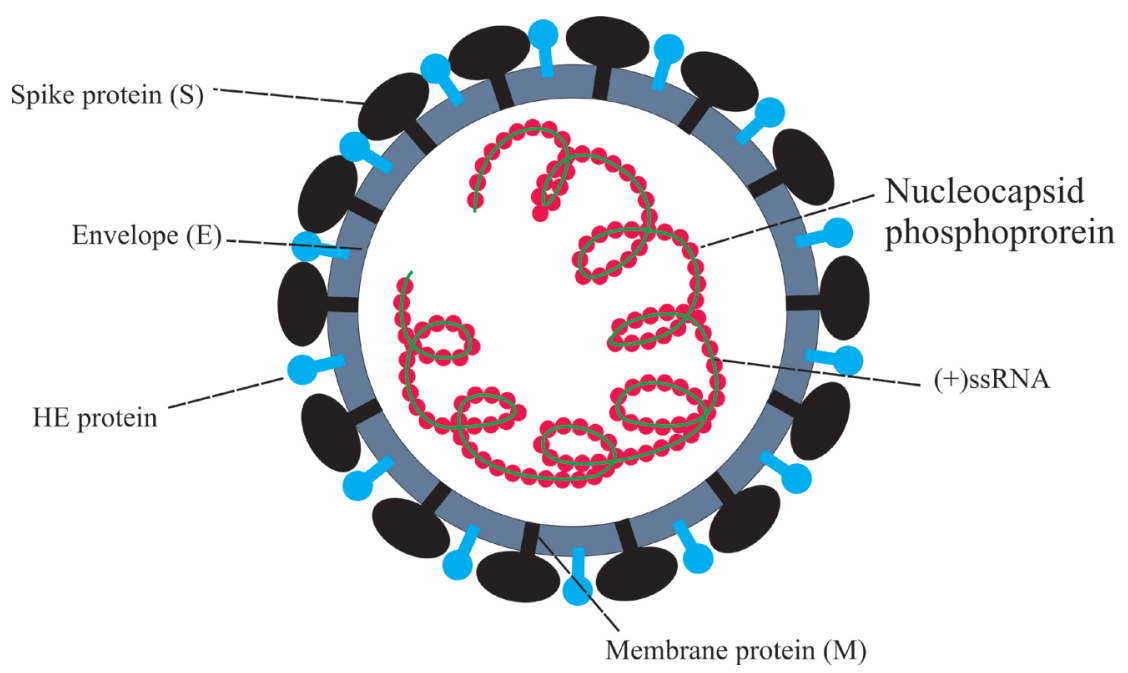

Fig. 1 A schematic model of a coronavirus.

study reported that some natural products such as lycorine, homoharringtonine, silvestrol, ouabain, tylophorine, and 7methoxycryptopleurine may possess potential antiviral activities at nanomolecular equivalent concentrations. ${ }^{13}$ Natural isolates or extracts such as scutellarein, silvestrol, tryptanthrin, saikosaponin B2, lectins such as griffithsin, lycorine and polyphenolics including quercetin, myricetin, caffeic acid, psoralidin and isobavachalcone were also shown to be active against human coronaviruses. ${ }^{14}$ Given the significance of natural products, particularly herbal preparations and phytochemicals, on viral infections, we tried to collect a list of plant species/bioactive components or antiviral herbal medicine formulations that are capable of combating viral infections in RNA viruses with emphasize on coronaviruses. We also provided a summary of different types of viruses and the family of coronaviruses.

\section{Methods}

\section{Study design}

Data were extracted from PubMed, Scopus, Google Scholar, and Science Direct, using the keywords "antiviral" OR "coronavirus" OR "RNA virus" OR "herbals" OR "plant species" OR "herbal preparation" OR "herbs" OR "herbal formulation" in the title/summary and the keywords "plant, herb, phytochemistry" in the whole text. The research results were included in the study, regardless of the time limitation. The final articles used in the current review were from 1983 to 2020 . 32\% of the references were from 2015 until 2020. Two persons independently evaluated studies and non-English and duplicates were excluded. We avoided studies on DNA viruses and focused on RNA viruses, specifically the coronavirus family. We also prioritized our work over studies that examined the antiviral mechanisms of plants and their derivatives.

\section{Data extraction}

A summary of information including the name of plants, essential oil, phytochemical compounds, and herbal formulation, method of study such as in vitro or in vivo, the model used in the assay, dosage of treatment, and finally the results of the study are presented in two tables.

\section{Study selection and characteristics}

Out of a total of 930 studies, 440 studies were deleted due to irrelevant title and abstract, 186 studies were excluded in repetitive, and 50 non-English studies were left out. In total, 22 studies remained to review the full text. A further 53 studies were discontinued due to the irrelevance of criteria in this study.

\section{Types of viruses}

Viruses only reproduce within individual species. Therefore, to facilitate the study, they are divided into vertebrate viruses, invertebrate viruses, bacterial viruses (bacteriophage), and plant viruses, depending on the type of host. Virus families are classified by the suffix-viridae. Today, viruses are classified considering to three major characteristics: nature and structure of the genome, viral symmetry nucleocapsids (icosahedral or helical), and general morphology. Nevertheless, other features are also used to viral classification: size, physiochemical properties; mechanisms of gene expression and virus replication; serological relationships; host and tissue susceptibility; and pathology. Vertebrate viruses are often classified according to their genomic content (DNA or RNA) (Table 1), singleor double-stranded, and linear or annular. ${ }^{15,16}$

\section{Double-stranded DNA (dsDNA) viruses}

There are many viruses with the dsDNA genome that infect mammals. They are divided into seven families: Hepadnaviridae, Polyomaviridae, Papillomaviridae, Adenoviridae, Herpesviridae, Poxviridae, and Asfarviridae. With the exception of the Poxviridae and Asfarviridae families, all families have members that can cause persistent infection in humans or animals. Hepadenoviruses, polyomaviruses, papillomaviruses, and viral herpes are causally linked to human cancers. This suggests that dsDNA viruses have many ways of disrupting and influencing cell division. Many details of their reproduction cycle indicate that they evolved from retroviruses. ${ }^{17}$ Genomic content of these viruses enter the host cell nucleus and mimics the genome of the host cell. Typically, the viral genome is replicated from the host cell using a DNA polymerase, and the viral genome is transcribed from the host cell by RNA polymerase. The resulting transcripts are then 


\begin{tabular}{|c|c|c|}
\hline Virus type & Example & Properties \\
\hline DNA viruses & Poxviruses, Herpes, Adenoviruses, Papillomaviruses & $\begin{array}{l}\text { Contain mostly double-stranded DNA, a small number single- } \\
\text { stranded DNA. DNA viruses enter the cell nucleus and direct the } \\
\text { generation of new viruses }\end{array}$ \\
\hline RNA viruses & $\begin{array}{l}\text { Influenza, Measles, Mumps, Cold, Meningitis, } \\
\text { Poliomyelitis, Retroviruses (AIDS, T-cell leukemia), } \\
\text { Arenaviruses, Coronaviruses }\end{array}$ & $\begin{array}{l}\text { Contain largely ssRNA. RNA viruses do not enter the cell nucleus } \\
\text { (except the influenza virus). RNA retroviruses use the viral reverse } \\
\text { transcriptase to make a DNA copy of the viral RNA, which is then } \\
\text { integrated into the host genome }\end{array}$ \\
\hline
\end{tabular}

ssRNA, single-stranded RNA.

transported to the cytoplasm and are replicated by the host cell ribosomes. Several replicated viral DNA molecules are converted to virions. Virions contain an entire virus particle, consisting of an outer protein shell called a capsid and an inner core of nucleic acid. Virions use the machinery of host cells to complete their life cycle and target other host cells, initiating new infection cycles. ${ }^{18}$

\section{Single-stranded DNA (ssDNA) viruses}

This type of virus is often identified by the presence of two genes; a gene for viral nucleocapsid protein and another gene as a DNA replication enzyme. Once these viruses enter the cells, viral ssDNA converts to dsDNA using host cell DNA polymerase using the $3^{\prime}$ end of viral DNA as the base template for transcription, resulting in the production of viral proteins. Then replicated viral DNA is reconverted into an ssDNA genome, which later might form virions. Parvoviruses in dogs and cats belong to the ssDNA virus family. ${ }^{19-22}$

\section{(+) Single-stranded RNA or (+) ssRNAs viruses}

This class is by far the largest group of viruses (i.e., many common cold viruses and the poliovirus) and consequently has considerable variety in terms of size, structure, organization, and observed replication strategy. ssRNAs are also known as picornaviruses because they have small RNA genomes. The ssRNA genome can act as an mRNA molecule, thus called "+". However, there are several common theme in genome organization, particularly unsegmented and single open reading frame (ORF) genomes, where the proteolytic lysis of a long "polyprotein" leads to mature gene products. Non-segmented genomes with multiple ORFs require two rounds of translation or subgenomic mRNA to express structural and non-structural proteins. According to this situation, there are multi-part genomes, each component has a single ORF. The virus genome in this class range in size from $5 \mathrm{~kb}$ (i.e., leviviruses) to $30 \mathrm{~kb}$ (i.e., coronaviruses). ${ }^{23}$

\section{(-) Single-stranded RNA or (-) ssRNAviruses}

The negative-strand RNA viruses are a broad group of animal viruses that comprise several important human pathogens, including influenza, measles, mumps, rabies, respiratory syncytial, Ebola, and hantaviruses. All these viruses are enveloped viruses whose genomes is consisted of either one (in paramyxoviruses, rhabdoviruses, filoviruses, and Bornadisease virus) or several (in orthomyxoviruses, bunyaviruses and arenaviruses) RNA segments. The virus carries its RNAdependent RNA polymerase, which is responsible for the transcription and replication of the viral genome in the infected cell. $^{24,25}$

\section{Double-stranded RNA (dsRNA) viruses}

Double-stranded RNA (dsRNA) molecules belong to a limited group of viruses such as Reoviruses with 10 different dsRNAs in their genomes. ${ }^{26}$ These viruses also contain the RNA replicase enzyme as a part of the virus structure. This enzyme transcribes positive RNA strands and helps the virus to complete the steps of its replication cycle alone, such as rotaviruses. ${ }^{27,28}$

\section{$(+)$ ssRNA retroviruses}

The retroviruses encompass a large family of infectious agents (Retroviridae) unified by a typical virion structure and mode of replication. Retroviruses genomes may serve as mRNA, consisting of a dimer of identical single-stranded RNA molecules, each 7-10 kb in length. Viruses with genomes higher than $8 \mathrm{~kb}$ are those that have other genes in addition to Gag, $P o l$, and Env. They use an enzyme called reverse transcriptase, giving them the unique property of transcribing their RNA into DNA after entering a cell. Once the virus enters the cell, instead of the RNA (+) strand, the virion RNA is used as a template to create a DNA copy of the viral genome through a viral enzyme called reverse transcriptase. This viral DNA becomes integrated into the host-cell DNA. Such viral DNA is called a "provirus", identical to the genes of host cells. This integrated provirus is transcribed into RNA ( + ) and is transported to the cytoplasm to be utilized for the synthesis of viral proteins, or as a genome for new viruses. Retroviruses are in effect retrograde because the flow of genetic information is reversed compared with the normal pathway of molecular biosynthesis: DNA to RNA and then to protein. These viruses are referred to as Human Endogenous Retroviruses or HERVs. $\mathrm{HIV}$ is a retrovirus and a member of the lentivirus. ${ }^{29,30}$

Approaches to counter virus infection should be adjusted according to the specific viral characteristics. To this end, today's medicines hit targets that minimize the risk of disease by disrupting the vital functions of the virus. Table 2 provides a summary of current medications with their mechanism of action for viral infections. There are several therapeutic targets for these drugs, which are also used to design new drugs. Considering the side effects of chemical drugs, the search for new drugs with similar properties and fewer side effects could fix a significant part of the health problems area.

\section{Coronaviruses; structure, genome, and lifecycle}

The family Coronaviridae includes the genus Coronavirus and Torovirus. Coronaviruses belong to the family Coronaviridae, suborder Cornidovirineae, order Nidovirales, and realm Riboviria. Coronaviruses are large enveloped positive-sense, ssRNA viruses of vertebrates by importance in medical and veterinary diseases. ${ }^{31}$ The same other RNA viruses, 
coronaviruses are highly mutant. However, the mutation rate might be somewhat lower than other RNA viruses because of its genome-encoded exonuclease, enabling the viruses to become more virulent and to extend more efficiently through different hosts. ${ }^{32}$ Coronaviruses are likely to have a seasonal distribution and may cause asymptomatic as well as lower and upper respiratory tract infections. ${ }^{33}$ It has been reported that human coronaviruses can infect neurons since viral RNA has been detected in the brain of patients with multiple sclerosis. ${ }^{34}$ Interest in this family of viruses has increased in recent years due to the identification of a newly emerging coronavirus as the causative agent of SARS and MERS. ${ }^{35,}{ }^{36}$ Until the appearance of SARS in 2003, only four human low-pathogenic; HCoV-OC43, HCoVHKU1, HCoV-NL63, and HCoV-229E, were recognized, of which types $229 \mathrm{E}$ and OC43 constitute a significant cause of the common cold and therefore were not high precedence for centralized research. ${ }^{37-39}$ Coronaviruses contain three significant proteins in their structure: the very large $(200 \mathrm{~K})$ glycoprotein S (spike) is the major inducer of neutralizing antibody, which forms the large $(15-20 \mathrm{~nm})$ peplomers in the virus envelope; an unusual transmembrane protein $(\mathrm{M})$; and an internal phosphorylated nucleocapsid protein $(\mathrm{N})$. Moreover, there is a tiny transmembrane protein $\mathrm{E}$, and some coronaviruses contain another coat protein with hemagglutination and esterase (HE) functions. ${ }^{40,41}$

Their $30-\mathrm{kb}(+)$ ssRNA is the largest known RNA virus genome with $\mathrm{G}+\mathrm{C}$ contents varying from $32 \%$ to $43 \% .{ }^{42}$ The viral genome contains distinctive features, including a unique $\mathrm{N}$-terminal fragment within the spike protein. SARS-CoV-2 binds to ACE2 (the angiotensin 2 converting enzyme) via its $S$ protein and enables the virus to penetrate and infect cells. To complete the virus entrance into the cells, the $S$ protein must be enzymatically prepared by a protease, for example, protease TMPRSS2 in the case of SARS-CoV and SARSCoV-2. TMPRSS2 facilitates the linkage of the virus receptor (S protein) to its cellular ligand (ACE2) ${ }^{43,44}$ (Fig. 1). Since the $S$ glycoprotein is surface-exposed and mediates the virus entry into host cells, also, the ACE2 could mediate SARS-CoV-2 S-mediated entry into cells, they both are the main targets of ongoing vaccine and therapeutic design efforts and for neutralizing polyclonal antibodies upon infection. ${ }^{45}$ Within the host cell, the virus undergoes uncoating, and then the genome

Table 2. Antiviral mechanisms of compounds as therapeutic targets in medical applications.

\begin{tabular}{|c|c|c|c|c|}
\hline Antiviral mechanism & Target virus (es) & Compounds approved & $\begin{array}{l}\text { Selected compounds in development } \\
\text { for the indicated target virus }\end{array}$ & Reference \\
\hline $\begin{array}{l}\text { Virus adsorption } \\
\text { inhibitors }\end{array}$ & $\begin{array}{l}\text { HIV, Herpesviruses (HSV), } \\
\text { CMV, RSV, and other } \\
\text { enveloped viruses }\end{array}$ & - & $\begin{array}{l}\text { Polysulphates, polysulphonates, } \\
\text { polycarboxylates, polyoxometalates, } \\
\text { chicoric acid, zintevir, cosalane } \\
\text { derivatives, negatively charged } \\
\text { albumins }\end{array}$ & $51-55$ \\
\hline $\begin{array}{l}\text { Viral DNA polymerase } \\
\text { inhibitors }\end{array}$ & $\begin{array}{l}\text { HSV }-1 \&-2, V Z V, C M V, E B V \\
\text { HHV-6, }-7,-8\end{array}$ & $\begin{array}{l}\text { Acyclovir, valaciclovir, } \\
\text { ganciclovir, valganciclovir, } \\
\text { penciclovir, famciclovir, } \\
\text { brivudin, foscarnet }\end{array}$ & $\begin{array}{l}\text { Bicyclic furopyrimidine } \\
\text { nucleoside analogues, A5021, } \\
\text { cyclohexenylguanine }\end{array}$ & $56-58$ \\
\hline Reverse transcriptase & HIV & $\begin{array}{l}\text { NRTIs: zidovudine, } \\
\text { didanosine, zalcitabine, } \\
\text { stavudine, lamivudine, } \\
\text { abacavir } \\
\text { NNRTIs: nevirapine, } \\
\text { delavirdine, efavirenz }\end{array}$ & $\begin{array}{l}\text { Emtricitabine, amdoxovir } \\
\text { Emivirine, UC781, DPC083, TMC125 } \\
\text { (R165335) }\end{array}$ & $59-63$ \\
\hline $\begin{array}{l}\text { Virus-cell fusion } \\
\text { inhibitors }\end{array}$ & $\begin{array}{l}\text { HIV, RSV, and other } \\
\text { paramyxoviruses }\end{array}$ & - & $\begin{array}{l}\text { HIV: AMD3100, TAK779 and T20 } \\
\text { derivatives }\end{array}$ & $64-66$ \\
\hline $\begin{array}{l}\text { Acyclic nucleoside } \\
\text { phosphonates }\end{array}$ & $\begin{array}{l}\text { DNA viruses (polyoma, } \\
\text { papilloma-, herpes-, } \\
\text { adeno- and poxviruses), } \\
\text { HIV, HBV }\end{array}$ & $\begin{array}{l}\text { CMV: cidofovir } \\
\text { HIV: tenofovir }\end{array}$ & HBV: adefovir & $67-69$ \\
\hline Viral protease inhibitors & $\begin{array}{l}\text { HIV, herpesviruses, } \\
\text { rhinoviruses, HCV }\end{array}$ & $\begin{array}{l}\text { HIV: saquinavir, ritonavir, } \\
\text { indinavir, nelfinavir, } \\
\text { amprenavir, lopinavir }\end{array}$ & $\begin{array}{l}\text { HIV: atazanavir, mozenavir, tipranavir } \\
\text { Human rhinovirus: AG7088 }\end{array}$ & $70-74$ \\
\hline $\begin{array}{l}\text { Inhibitors of processes } \\
\text { associated with viral RNA } \\
\text { synthesis }\end{array}$ & HIV, HCV & - & - & 75 \\
\hline $\begin{array}{l}\text { Viral neuraminidase } \\
\text { inhibitors }\end{array}$ & Influenza $A$ and $B$ virus & Zanamivir, oseltamivir§ & RWJ270201 & $76-79$ \\
\hline $\begin{array}{l}\text { IMP dehydrogenase } \\
\text { inhibitors }\end{array}$ & HCV, RSV & Ribavirin & Mycophenolic acid, EICAR, VX497 & $80-82$ \\
\hline $\begin{array}{l}\text { S-adenosylhomocysteine } \\
\text { hydrolase }\end{array}$ & $\begin{array}{l}\text { (-) RNA hemorrhagic } \\
\text { fever viruses (for example, } \\
\text { Ebola) }\end{array}$ & - & - & 83,84 \\
\hline
\end{tabular}


is transcribed and translated. As mentioned earlier, the positive-stranded viral RNA serves as mRNA for the translation of the two large ORFs (ORF 1a and 1b), each coding for the RNA polymerase units, depending on the RNA. Upon cleavage, these proteins covert to the active RNA polymerase, forming a full-length complementary RNA (negative sense). Cytoplasmic membranes are the site of coronavirus replication and transcription. These membranes modulate both continuous and discontinuous RNA synthesis through a viral replica, a large protein complex encoding the $20 \mathrm{~kb}$ replicase gene. ${ }^{46}$ Based on the genome size, numerous genetic recombination can happen between different but related coronavirus genomes, which is a critical mechanism for the genetic diversity of coronaviruses in nature. ${ }^{47}$ During maturation and assembly, protein $\mathrm{S}$ is co-translationally inserted into the rough endoplasmic reticulum (RER) and is glycosylated with $\mathrm{N}$-linked glycans. Glycosylation is a crucial stage for protein $S$ function and transportation. Protein $S$ forms trimers before being exported from ER, and then interacts with proteins $M$ and $\mathrm{E}$ to translocate to the site of virus assembly. SARS-CoV expresses another structural protein which is called $3 \mathrm{a}$. This protein is associated with both the intracellular and plasma membranes, and can induce programmed cell death (apoptosis). Protein $\mathrm{S}$ is crucial for virus entry, but not for its assembly ${ }^{48-50}$ (Fig. 2).

\section{Herbal preparations and antiviral mechanisms}

Medicinal herbs, especially those used in folk medicine, have been highly regarded in the treatment of viral diseases because they contain bioactive substances that can be used to produce antiviral drugs with minimal side effects. Several secondary plant metabolites such as essential oils, flavonoids, saponins, tannins, alkaloids, lignans, terpenes, and phenolic acids shown significant antiviral activities against various viruses. ${ }^{85}$, ${ }^{86}$ Indeed, those elements that interfere with certain stages of viral biosynthesis, for example, the replication cycle, are the best for clinical antiviral approaches. Low concentrations and minimum effects on host cell machinery are the main privileges of these drugs, which ultimately leads to cure of infected cells. On the other hand, virucidal drugs denature viral structural proteins or glycoproteins, which results in a total loss of the infectivity of the viral particles. The therapeutic approach, as well as herbal derivatives, could apply different strategies to inhibit virus function. It is known that both protein and lipid-protein of capsids must protect the nucleic acid inside the virus from the harmful substances, and facilitate the surface absorption of the virion into the host cell. The invasion of a cell by a viral particle always depends on its specific and close connection to one of the surface components of the host cell's plasma membrane. ${ }^{87}$ Some plants use this mechanism to abolish the virus entry into the host cell by blocking their attachments to the cell surface. ${ }^{88}$ Most RNA viruses propagate in the cytoplasm because they have all the enzymes needed for in their genome. ${ }^{89}$ This step may be a therapeutic target for some herbal compounds due to their inhibitory effects. ${ }^{90}$ The HIV protease enzyme is responsible for the proteolytic cleavage between gag and gag-pol precursor polypeptide, which in turn converts them into functional forms and ensures the viral maturation and infectivity. The HIV polymerase inhibitors show their activity at the end of virus replication and therefore interfere with active virus formation functionally. ${ }^{91,92}$ Many active plant compounds act as HIV protease inhibitors are shown in in-vitro assays. ${ }^{93}$ Besides, the HIV integrase enzyme performs two main functions: the entry of pre-viral complexes into the nuclear pores and then the integration of the viral DNA genome into the host cell chromosome. ${ }^{94}$ The effectiveness of some herbs in inhibiting this enzyme has reduced the proliferation of the HIV-1 virus. ${ }^{95}$ Some phytochemicals have been studied, and results indicated their efficiency in integrase activity. ${ }^{96}$ The influenza virus NA causes the release of the virus from the host cell surface by catalysis a breakdown in the silicic acid attached to glycoprotein and glycolipid. ${ }^{97,98}$ The inhibition of this enzyme can be considered as one of the therapeutic targets in medicinal plant studies. ${ }^{99}$ It is well evidenced that many plants contain ribosome-inactivating proteins (RIPs) with $\mathrm{N}$-glycosidase activity that can affect ribosomal function through depurination of large ribosomal rRNAs in infected cell and Inhibition of viral protein synthesis. RIPs

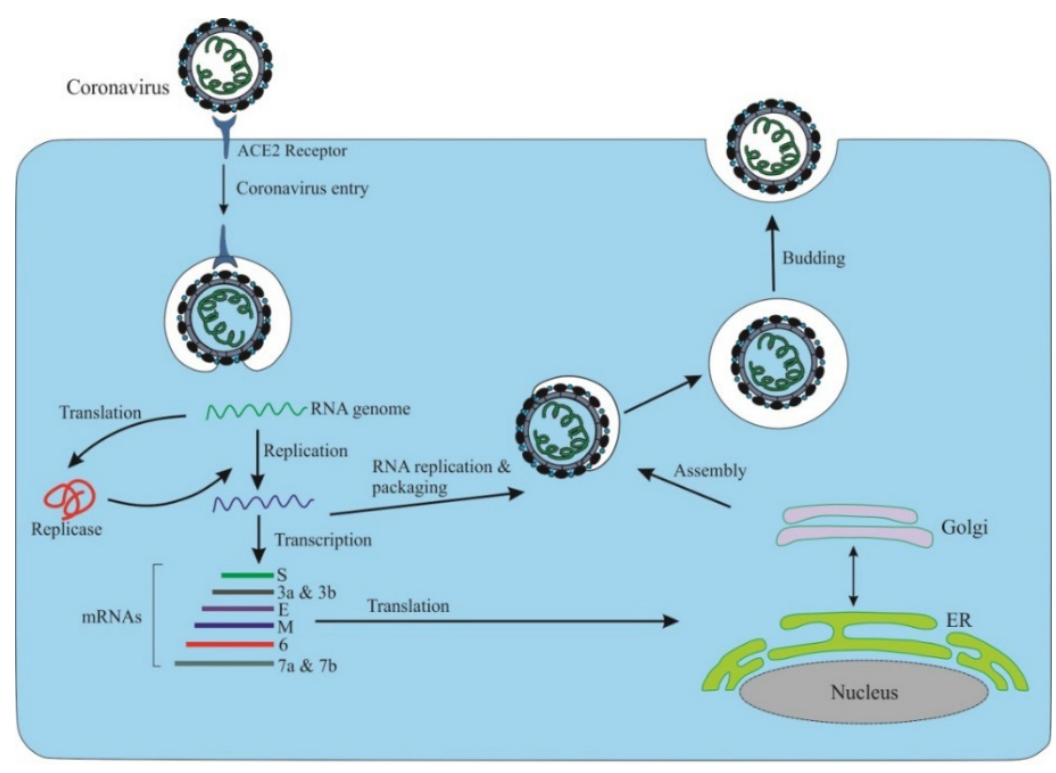

Fig. 2 A viral cycle of a coronavirus in the host cell. 
can inhibit viral mRNA and DNA replication. Depurination is defined as inactivation of ribosomes by removal of a specific adenine from the sarcin/ricin (S/R) loop of the large rRNA, thereby inhibiting translation. To date, RIPs were shown effective against HIV, HBV, and HSV. For example, Trichosanthin (Trichosanthes kirilowii), PAP (Pokeweed americana), GAP31 (Gelonium multiflorum) and MAP30 (Momordica charantia) have been reported to inhibit HIV-1 replication in vitro. ${ }^{100,101}$ In following sections, we prepared a list of herbal preparations, essential oils, and phytochemicals that were able to inhibit the activity of the coronaviruses family.

\section{Herbal extracts}

To date, numerous herbal preparations were investigated against various types of viruses. Table 3 represents plant species, and those were shown valid on coronaviruses.

\section{Morus spp.}

Antiviral properties of the leaves and the stem bark of the mulberry tree (Morus spp.) were evaluated in human coronavirus (HCoV 229E) in L-132 cells. It was shown that Morus spp. reduced the viral titer and the cytopathogenic effects. The hydroalcoholic extract of the leaves exhibited the highest antiviral activity. The inhibition percentage of viral infectivity ranged from $34 \%$ to $36 \%$ for the aqueous stem bark extracts and from $37 \%$ to $45 \%$ for the hydromethanolic stem bark extracts. In comparison, this inhibition ranged from $67 \%$ to $100 \%$ for the hydromethanolic extracts of leaves. ${ }^{102}$

\section{Echinacea purpurea}

Antiviral potential of E. purpurea examined against $\mathrm{HCoV}$ 229E and the highly pathogenic MERS- and SARS-CoVs in vitro. $\mathrm{HCoV}-229 \mathrm{E}$ was irreversibly inactivated when exposed to Echinaforce (a commercial standardized extract of E. purpurea) at an $\mathrm{IC}_{50}$ of $3.2 \mu \mathrm{g} / \mathrm{ml}$. Pre-treatment of cell lines had only a marginal effect on virus propagation at $50 \mu \mathrm{g} / \mathrm{ml} .{ }^{103}$

\section{Uvaria angolensis}

The methanolic extract of the stem bark of $U$. angolensis inhibited both the HIV-1 RNase $\mathrm{H}$ enzyme and the reverse transcriptase activities with $\mathrm{IC}_{50}$ values of $1.0 \pm 0.2$ and $0.62 \pm 0.15 \mu \mathrm{g} / \mathrm{mL}$, respectively. RDS1643 and Efavirenz were considered as control of RNase $\mathrm{H}$ inhibitor and reverse transcriptase, respectively. The $\mathrm{IC}_{50}$ values for RDS1643 were measured as $2.7 \pm 0.2 \mu \mathrm{g} / \mathrm{mL}^{104}$

\section{Pometia pinnata}

Leaf and bark of $P$. pinnata have traditionally been used to treat fever and fester. The ethanolic extracts of $P$. pinnata (Sapindaceae) leaves have shown one of the most potent inhibitory activity against $\mathrm{HIV}-1$ integrase in vitro with an $\mathrm{IC}_{50}$ value of $8.8 \mu \mathrm{g} / \mathrm{mL}$. In this study, proanthocyanidin A2 was isolated as an anti-HIV-1 integrase compound, with an $\mathrm{IC}_{50}$ value of $30.1 \mu \mathrm{M} .^{95}$

\section{Anthemis hyalina}

Antimicrobial activities of different species in the genus of Anthemis have been documented. Treating HeLa CEACAM1 cells infected coronavirus MHV-A59 with the ethanoic extract of Anthemis hyaline decreased the proliferation and function of this virus. However, this herb has a positive effect on IL-8 secretion and expression of transient receptor potential proteins (TRP) family genes, and its primary role was reducing the viral load. ${ }^{105}$

\section{Phyllanthus amarus}

The hydroalcoholic extract of $P$. amarus leaves inhibited the interaction of HIV-1 envelope gp120 protein with its CD40 cell receptor up to $50 \%$. Inhibition of virus envelope protein gp120 binding to the cellular receptor CD4 was the primary mechanism underlying the blocked virus entry. The extract also showed an inhibitory effect on other enzymes of the virus, such as reverse transcriptase, integrase, and protease. ${ }^{106}$

\section{Glycine max or Black soybean}

An aqueous/ethanol extract of black soybean inhibited respiratory tract viruses such as human adenovirus type 1, coxsackie B1, and influenza A in Vero, HeLa, MDCK, and FL cell lines in a dose-dependent manner. Ethanolic extract from black soybean demonstrated dose-dependent inhibitory activity against human adenovirus type 1 replication. The antiviral index was about $1.5 \mathrm{mg} / \mathrm{ml}$, and significant activity was recorded at $3.5 \mathrm{mg} / \mathrm{ml} .^{107}$

\section{Sambucus nigra}

In a placebo-controlled randomized, double-blind study, oral administration of elderberry (Sambucus nigra) extract was shown to be an effective, safe, and cost-saving healing agent in influenza patients. In this study, patients received $15 \mathrm{ml}$ of elderberry syrup for 5 days, and they recorded their symptoms on a visual analog scale. Compared with placebo, respiratory influenza symptoms improved 4 days earlier, and their need for medication decreased. ${ }^{108}$

\section{Geranium sanguineum}

Geranium sanguineum belonging to Geraniaceae is one of the medicinal plants rich in polyphenols, which reduces infection of various types of influenza viruses (H7N1, H7N7, and H3N2) in chicken embryo fibroblasts, MDCK cell lines and ICR mice (10 mg/kg in mice). n-butanol/ethanol and the ethanol/acetic acid fractions showed the highest antiviral effects in vitro and in vivo, respectively. ${ }^{109}$

\section{Boehmeria nivea}

Boehmeria nivea root extract reduced Hepatitis B virus (HBV) replication in vitro (in HepG2 2.2.15 cell). Real-time PCR, Southern blot and Northern blot techniques were used in this study to assay viral gene expression and replication. ${ }^{110}$

\section{Polygonum cuspidatum}

Different extracts of P. cuspidatum was shown to inhibit various viruses. This effect was associated with the presence of a class of the chemical group called anthraquinones. Anthraquinones have been reported to possess antiviral and virucidal activities against various types of viruses. Ethanolic extract of $P$. cuspidatum inhibited the HBV replication in a dose-dependent manner in the stable HepG2 2.2.15 hepatoblastoma cell line. ${ }^{11}$

\section{Guazuma ulmifolia}

G. ulmifolia, also known as mutamba, has therapeutic effects such as wound healing, antiulcerogenic, hypoglycemic and 


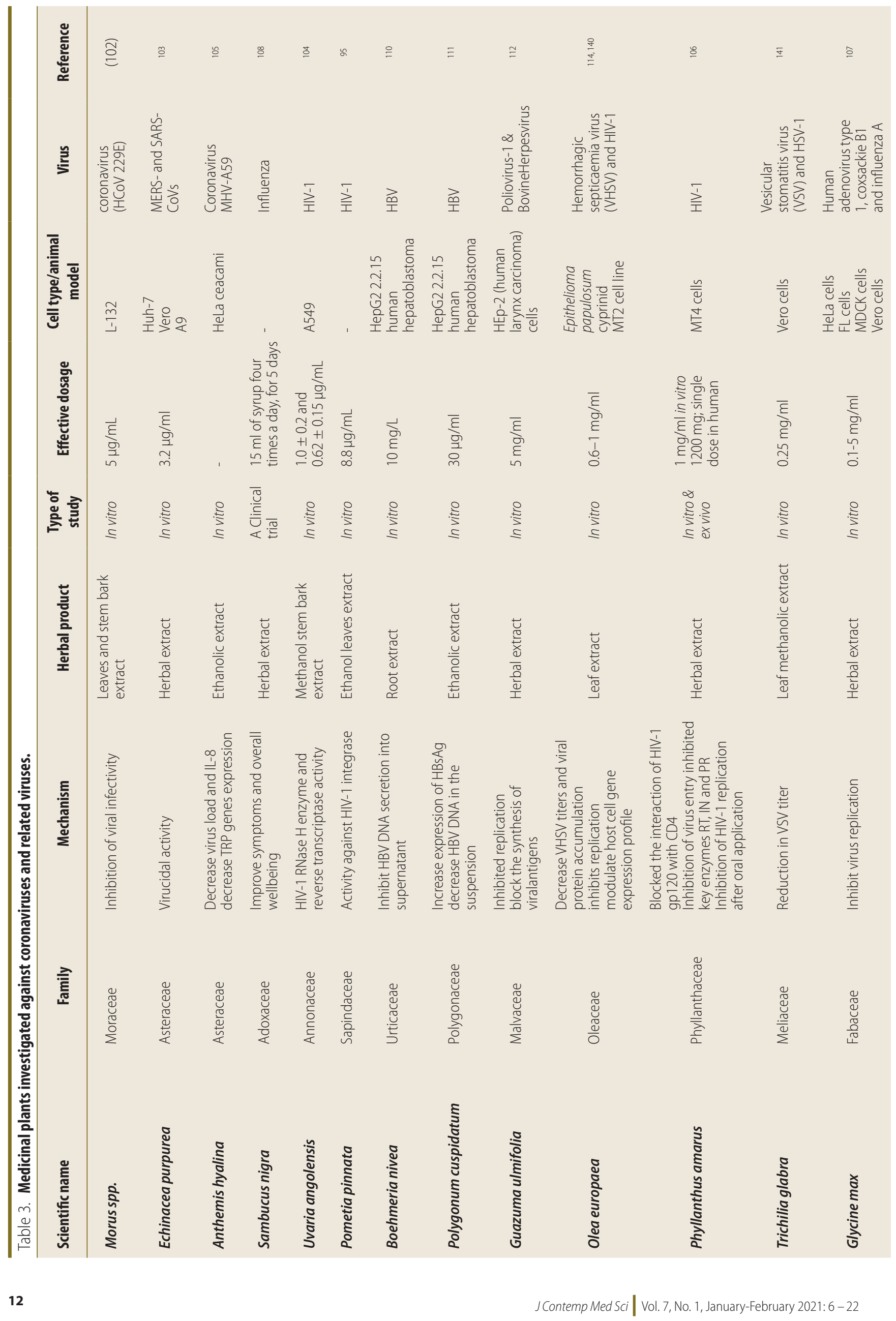




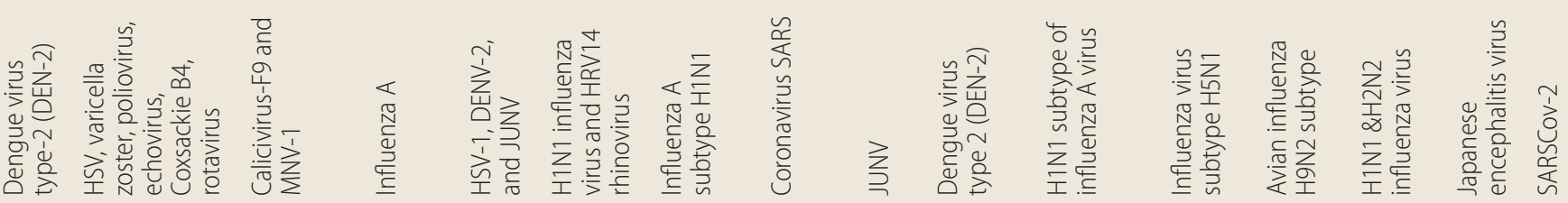
$\stackrel{\stackrel{\Xi}{\equiv}}{\overline{\bar{U}}}$

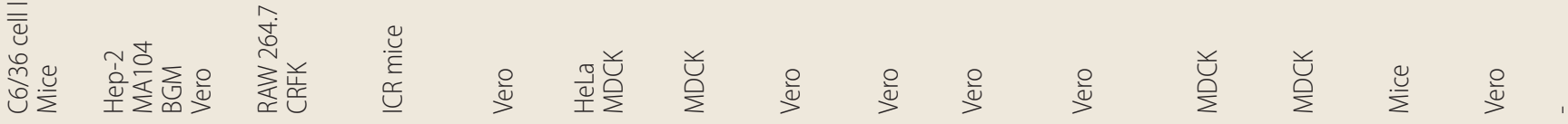

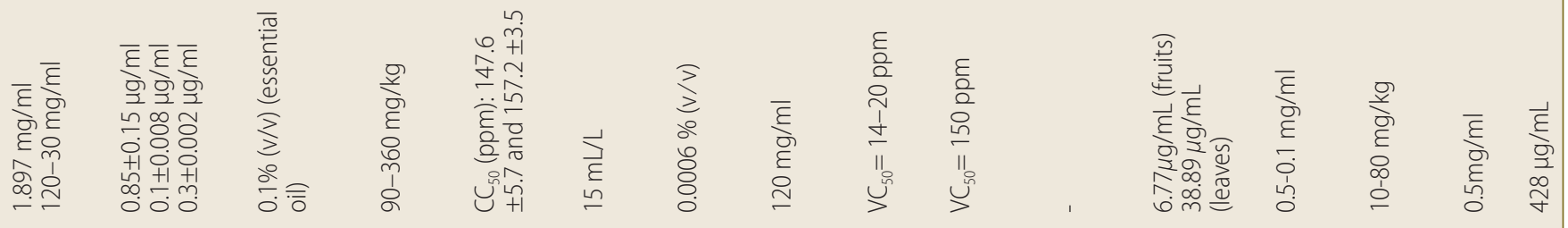

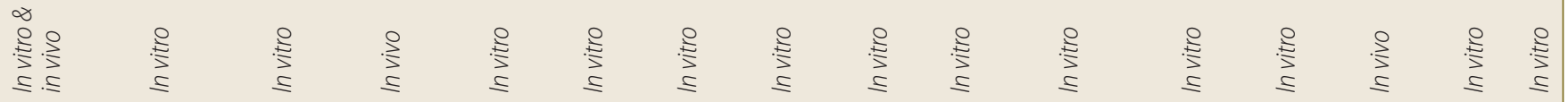

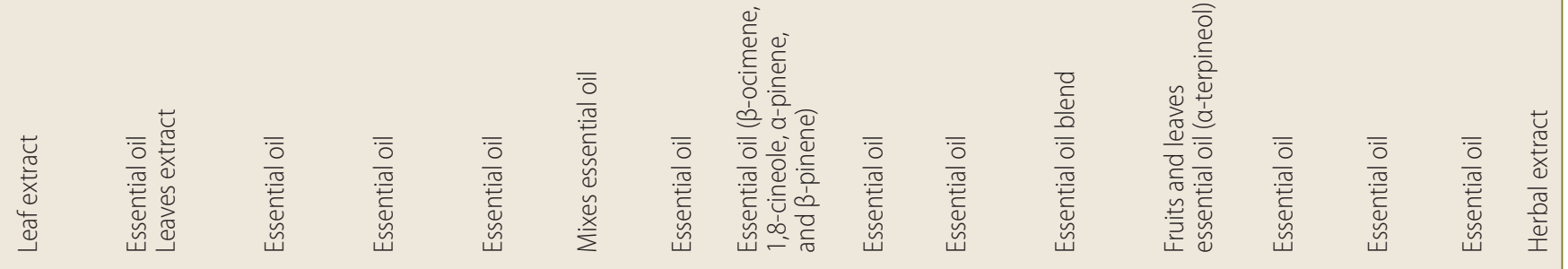

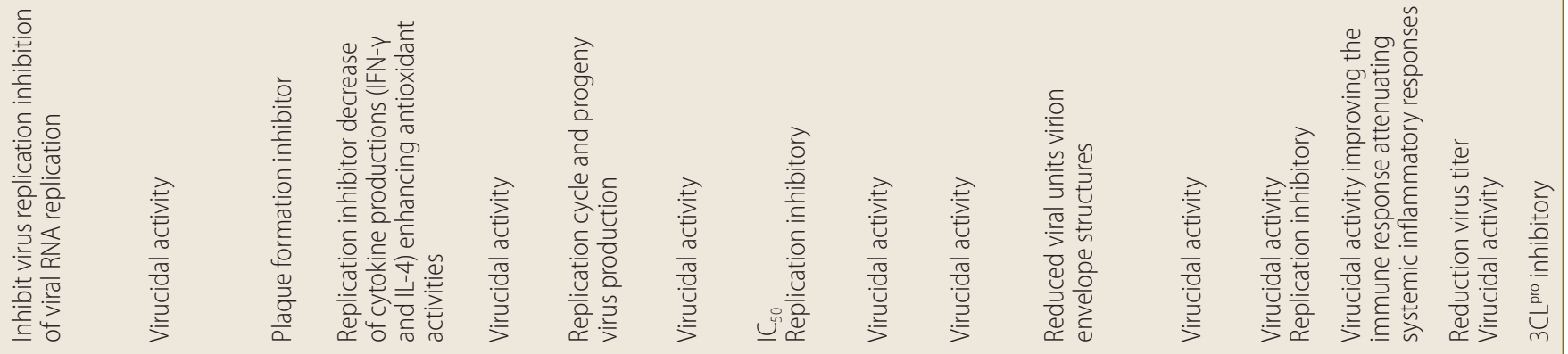

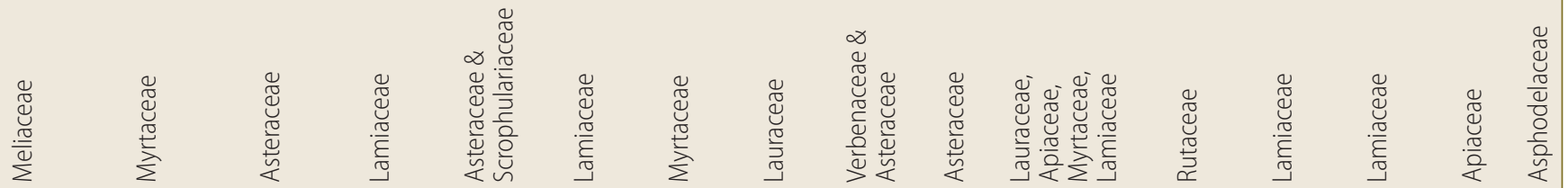
\|\|\|\|\|\|\|\|\|\| 
antimicrobial. G. ulmifoli extract inhibited poliovirus-1 replication by $26 \%$ in HEP- 2 cells and restricted the synthesis of viral antigens in the infected cell culture. ${ }^{112}$

\section{Azadirachta indica}

Azadirachta indica (Neem) is grown in tropical countries and has been reported to possess anti-inflammatory, antipyretic, and hypoglycemic activities. The aqueous extract of the leaves of $A$. indica inhibited Dengue virus type-2 (DEN-2) in vitro C6/36 cell line and in vivo (mice). ${ }^{113}$

\section{Olea europaea}

Olive leaf extract inhibited replication of viral hemorrhagic septicaemia virus (VHSV). ${ }^{114}$ The extract also inhibited acute infection and cell-to-cell transfer of HIV-1 virus in MT2 cell line. ${ }^{115}$

\section{Aloe vera}

A set of experiments suggested that $A$. vera has potent antiviral activity. $A$. vera contains bioactive virucidal compounds such as anthraquinones. As mentioned, anthraquinones like some antiviral drugs (Lopinavir, ritonavir), alone or in combination with other medications, can target SARSCov-2 protease 3CLPro. ${ }^{116}$ Acemannan is the predominant acetylated polysaccharide mannan extracted from $A$. vera gel and has been approved by the US FDA for the treatment of HIV-1 in humans. Acemannan inhibits glycosylation of viral proteins and inhibits cell fusion and suppression of virus release. ${ }^{17}$

\section{Essential oils}

Essential oils contain a large number of compounds and may target several purposes. However, in most cases, synergistic mechanisms are involved in their antimicrobial activity Studies have shown essential oils are complex mixtures of lipophilic and volatile secondary metabolites isolated from plants such as monoterpenes (hydrocarbon and oxygenated monoterpens), sesquiterpenes (hydrocarbon and oxygenated sesquiterpens), and/or phenylpropanoids that are responsible for a broad biological functions such as antimicrobial, antioxidant, anti-inflammatory, anticancer, cancer chemoprotective, repellent and insecticidal, allelopathic, cytotoxicity, and antiviral activities. ${ }^{118,119}$

\section{Laurus nobilis}

The essential of the leaves of $L$. nobilis has been shown to have potent antiviral activity against coronavirus SARS. The most important compounds in the essence of this herb include $\beta$-ocimene, 1,8-cineole, $\alpha$-pinene, and $\beta$-pinene. The $\mathrm{IC}_{50}$ of $L$. nobilis was measured $120 \mathrm{mg} / \mathrm{ml}$ with a selective index of 4.2 $\left(\mathrm{SI} ; \mathrm{TC}_{50} / \mathrm{IC}_{50}\right) .120$

\section{Mosla dianthera}

This herb is used as an aromatic herb in traditional medicine in the treatment of cough, colds, fever, bronchitis, nasal hyperemia, and headache. The effect of the essential oil of this herb on mice infected by influenza A was investigated. It was found that this essence has significant effects, including reducing viral lung titers, inhibiting pneumonia, lowering serum levels of IFN- $\gamma$ and interleukin 4 (IL-4), and enhancing the antioxidant activity in lung tissue of mice infected with influenza A. ${ }^{121}$

\section{Coridothymus capitatus, Origanum dictamnus and Salvia fruticosa}

A mixture of aromatic plant essential oils consisted of C. capitatus, O. dictamnus, and $S$. fruticosa was tested against the H1N1 influenza virus and HRV14 rhinovirus in HeLa and MDCK cells. It was found that this compound caused a defect in the nucleoprotein trafficking of the virus in vitro, thereby, has the potential to be used as an herbal drug against respiratory system viruses such as $\mathrm{H} 1 \mathrm{~N} 1$ influenza and rhinovirus HRV $14 .{ }^{122}$

\section{Melaleuca alternifolia}

The antiviral effect of this essence on the MDCK cell line was investigated using plaque reduction assay. The results of this study confirmed the antiviral activity of the essence of M. alternifolia against influenza A subtype $\mathrm{H} 1 \mathrm{~N} 1$, which was implicated to the presence of terpinen-4-ol, as the essence active ingredient. ${ }^{123}$

\section{Eucalyptus camaldulensis}

The essential oil of E. camaldulensis reduced the proliferation of Coxsackie B4, rotavirus, and herpes simplex virus (HSV). Moreover, the methanolic extract of this plant attenuated the activity of HSV, varicella zoster, poliovirus, and echovirus. ${ }^{124-126}$

\section{Artemisia princeps}

The essential oil of $A$. princeps var. orientalis and its bioactive components, including Borneol, Athujone, and Camphor, were studied on two noroviruses; MNV-1 and calicivirus-F9 by time-of-addition plaque assays. The $A$. princeps essence at concentrations of 0.1 and 0.01 inhibited the growth of calicivirus-F9 and MNV-1 by $48 \%$ and $64 \%(v / v)$, respectively. Borneol and Camphor showed no antiviral activity, whereas Athujone, the major compound of the essence, strongly and dose-dependently inhibited virus infection. ${ }^{127,128}$

\section{Heterothalamus alienus and Buddleja cordobensis}

In a study on seven herbs (Pectis odorata, Gaillardia megapotamica, Heterothalamus alienus, Aloysia triphylla, Artemisia mendozana, Jungia polita, Buddleja cordobensis) indigenous to the South America, their cellular properties (cytotoxicity) and their inhibitory effects on HSV-1, Dengue Virus Type 2 (DENV-2) (causing Dengue fever, Dengue hemorrhagic fever, and Dengue shock syndrome), and Junin virus (JUNV) (the cause of Argentine hemorrhagic fever) were evaluated. The strongest association between cytotoxicity and antiviral activities was observed for the essence of Hetero-thalamus alienus and B. cordobensis against JUNV virus. ${ }^{129}$

\section{Lippia junelliana and Lippia turbinate}

The essential oils of South American species named as $L$. junelliana and L. turbinate could temperature- and timedependently inhibit JUNV in Vero cells in vitro $\left(\mathrm{VC}_{50}\right.$ : 14-20 ppm). ${ }^{130}$

\section{Eupatorium patens}

The essential oil of the leaves, flowers, and fruits of E. patens (Asteraceae), indigenous to South America, potently restrained the DEN-2 replication (VC50: $150 \mathrm{ppm}$ ). The 
main components of the essential oil were D-germacrene; $\beta$-caryophyllene; bicyclogermacrene; $\alpha$-pinene; caryophyllene oxide. $^{130}$

\section{Cinnamomum zeylanicum, Daucuscarota, Eucalyptus globulus and Rosmarinus officinalis}

The blend of essential oil of these herbs inhibited H1N1 subtype of influenza A virus function, probably through interfering the formation of the virus coat and inhibiting its DNA polymerase enzyme. For H1N1, a reduction was greater than $99 \% .{ }^{131-133}$

\section{Fortunella margarita}

The essential oil compound of the fruit and leaves of F. margarita was found effective against avian influenza virus subtype H5N1 in MDCK cell line, which was associated with the presence of $\alpha$-terpineol in its fruit. The fruit essential oil has been shown to be more effective and caused an $80 \%$ inhibition of the virus activity. ${ }^{134}$

\section{Melissa officinalis}

The inhibitory effect of the essential oil of $M$. officinalis on the avian influenza H9N2 subtype was investigated in the MDCK cell line. It has been found that this herb has a synergistic effect in inhibiting the H9N2 virus with Noseltamivir. M. officinalis can interact with cell surface proteins (i.e., masking the cell surface), thereby blocking the virus binding to cellular receptors. ${ }^{135}$

\section{Pogostemon cablin}

The antiviral activity of the essential oil obtained from $P$. cablin has been demonstrated against $\mathrm{H} 1 \mathrm{~N} 1$ and $\mathrm{H} 2 \mathrm{~N} 2$ influenza virus. Oral administration of $P$. cablin essential oil in mice has also been shown to protect against influenza virus infection by enhancing the immune response and decreasing the systemic and pulmonary inflammatory response. ${ }^{136-138}$

\section{Trachyspermum ammi}

The essential oil of T. mumammi was found efficient against the Japanese encephalitis virus (JEV) in vitro. JEV titration was determined by plaque assay, and the antiviral activity of this plant was measured in vitro using a plaque reduction neutralization test. Treatment of Vero cell line with this essential oil in both pre- and post-exposure treatments reduced the virus titers by $80 \%$ and $40 \%$, respectively. ${ }^{139}$

\section{Herbal active biochemicals}

\section{Cinnamaldehyde}

Cinnamaldehyde, an abundant aromatic phenylpropanoid in Cinnamomi cortex (Cinnamomum verum) has been studied for its potential properties against the influenza virus. The results of reverse transcription (RT-PCR) and sodium dodecyl sulfate-polyacrylamide gel electrophoresis (SDS-PAGE) analyses showed that cinnamaldehyde inhibited the synthesis of influenza virus proteins at the post-transcriptional level. In mice infected with influenza virus, inhalation $(50 \mathrm{mg}$ in the cage daily) and nasal inoculation ( $250 \mathrm{~g}$ for each rat daily) of this compound over 8 days increased the survival rate from $20 \%$ to $100 \%$ and $70 \%$, respectively. Importantly, inhalation of cinnamaldehyde reduced virus titers in the bronchoalveolar lavage on the sixth day after infection ${ }^{142}$ (Table 4).

\section{5,7,3', 4'-tetrahydroxy-2' - (3,3-dimethylallyl) isoflavone}

5,7,3', 4'-tetrahydroxy-2' - (3,3-dimethylallyl) isoflavone, is extracted from Psorothamnus arborescens. The antileishmanial property of this compound has already been proven in the scientific literature. Chymotrypsin virus-like cysteine protease enzyme $\left(3 \mathrm{CL}^{\mathrm{pro}}\right)$ is an essential factor for the replication cycle of coronavirus, representing a potential target for the treatment of such disease. This compound has a high affinity to the catalytic domain of $3 \mathrm{CL}^{\text {pro }}$ enzyme. It also can bind receptor-binding residues of the $3 \mathrm{CL}^{\text {pro143, }} 144$ (Table 4).

\section{1,2,3,4,6-penta-O-galloyl- $\beta$-D-glucoside}

A compound called 1,2,3,4,6-penta-O-galloyl- $\beta$-D-glucoside, extractable from the aerial parts of Saxifraga melanocentra, is responsible for the anti-hepatitis $\mathrm{C}$ virus (HCV) effect of the herb. The compound was also a potent inhibitor of the HCV serine protease enzyme ${ }^{145}$ (Table 4 ).

\section{Myricitrin and Scutellarin}

Myricitrin can be obtained from a plant called Myrica cerifera. It also can bind to and inhibit the catalytic domain of $3 \mathrm{CL}^{\text {pro }}$ enzyme with high affinity. Modeling analysis also showed that Scutellarin or Myristine from Scutellaria baicalensis could directly link the ATP/ADP binding site of the SARS-CoV virus helicase enzyme (nsP13), thereby preventing direct binding of ATP/ADP to it. In particular, Myricetin interferes with the ATPase activity of the SARS-CoV protein helicase. It is likely to do so by directly interacting with essential residues of the ATPase domain, such as N265, Y269, and R443 $3^{146,147}$ (Table 4).

\section{Glycyrrhizin and Licorine}

Glycyrrhizin, the bioactive component of Licorice and Lycorine from red spider lily (Lycoris radiata), exhibited a potent anti-SARS-CoV Corona activity. However, the effective concentration of Glycyrrhizin $\left(\mathrm{EC}_{50}\right)$ for inhibiting viral infection was very high (EC50 $300 \mathrm{mg} / \mathrm{L})$. Glycyrrhizin was most effective when given both during and after the adsorption period ${ }^{148,149}$ (Table 4).

\section{Quercetin}

Quercetin is the most abundant dietary plant pigment flavonoid (i.e., in onion and garlic). It was reported that this compound inhibited the activity of $3 \mathrm{CL}^{\text {Pro }}$ of SARS-CoV with a FRET method. Its shown quercetin has low toxicity to the cells in vitro. Their MERS-CoV 3CL pro inhibitory activity is lower than their corresponding compounds at $40 \mu \mathrm{M}^{150}$ (Table 4).

\section{Baicalein}

Scutellaria baicalensis is one of the genus that may use as a source of this flavonoid. Ethanolic extract of $S$. baicalensis inhibited SARS-CoV-2 3CL pro activity in vitro and the replication of SARS-CoV-2 in Vero cells with an EC50 of $0.74 \mu \mathrm{g} / \mathrm{ml}$. Baicalein strongly inhibited SARS-CoV-2 3CL pro activity with an $\mathrm{IC}_{50}$ of $0.39 \mu \mathrm{M}^{151}$ (Table 4). 


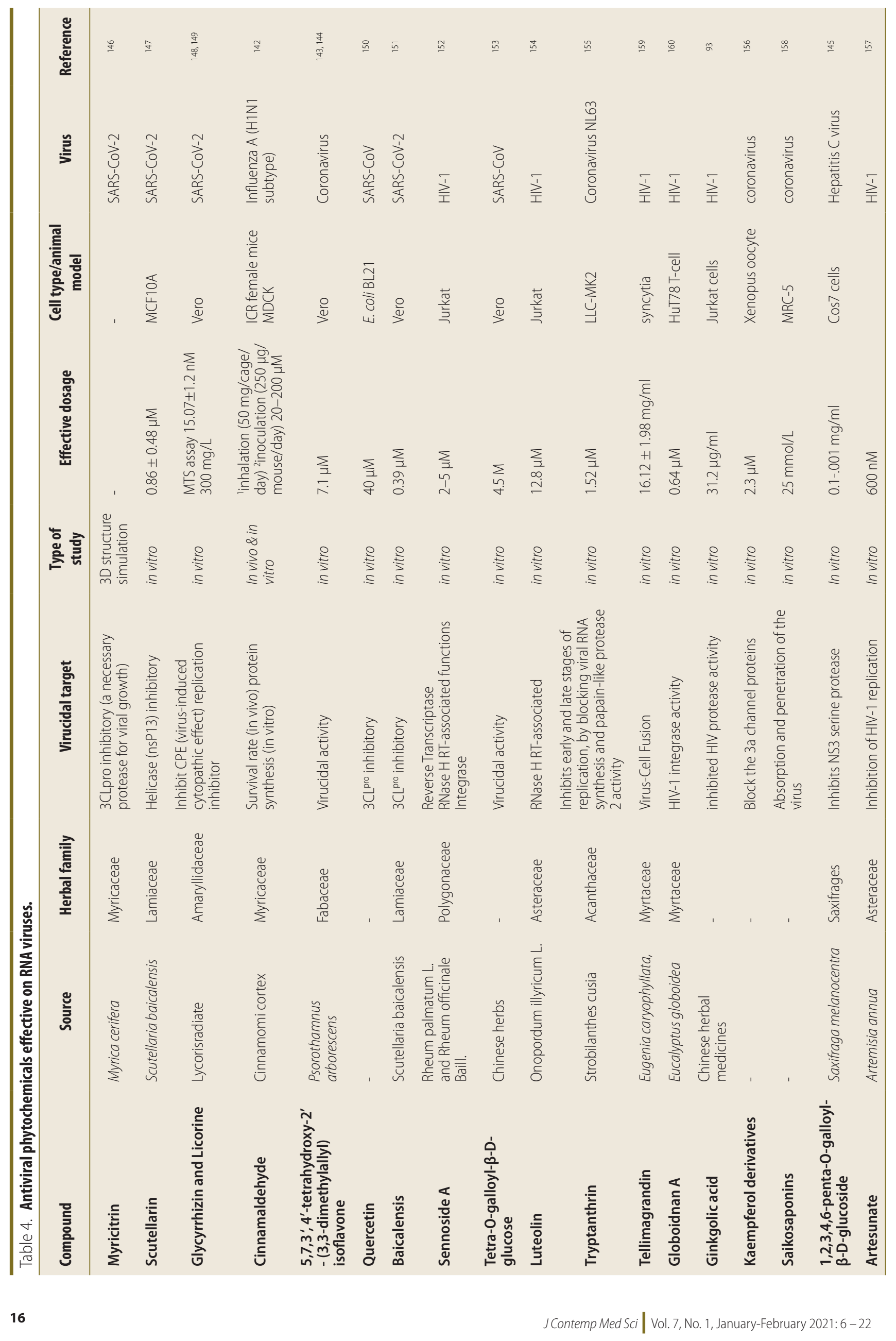




\section{Sennoside A}

Sennoside A from dried roots of Rheum palmatum L. and Rheum officinale Baill is HIV-1 RT inhibitor effective phytochemical on both HIV-1 Reverse Transcriptase and RNase H RT-associated functions in biochemical assays. Besides, Sennoside A affected the HIV-1 integrase activity in vitro and HIV-1 replication in Jurkat cell line. Sennoside A inhibited both HIV-1 RT-associated functions with $\mathrm{IC}_{50}$ values of 2-5 $\mu \mathrm{M}$ range. ${ }^{152}$ (Table 4$)$.

\section{Tetra-0-galloyl- $\beta$-D-glucose}

This small molecule from Chinese herbs exhibited prominent anti-SARS-CoV activity with a $\mathrm{EC}_{50}$ concentration of $4.5 \mathrm{M}$ in Vero E6 cells ${ }^{153}$ (Table 4).

\section{Luteolin}

Among seven compounds isolated from Onopordum illyricum L., Luteolin was the most effective on HIV-1 RNase H RT-associated function in a low concentration without cytotoxicity $\left(\mathrm{IC}_{50} \text { of } 12.8 \mu \mathrm{M}\right)^{154}$ (Table 4 ).

\section{Tryptanthrin}

The antiviral activity of Tryptanthrin isolated from Strobilanthes cusia was investigated against coronavirus NL63 in LLC-MK2 cell line. Tryptanthrin effectively inhibited the cytopathic effect and virus yield $\left(\mathrm{IC}_{50}=1.52 \mu \mathrm{M}\right)$ in HCoV-NL63-infected cells. This molecule prevented the early and late stages of HCoV-NL63 replication, mainly by blocking the viral RNA genome synthesis and papain-like protease 2 activity $^{155}$ (Table 4).

\section{Kaempferol derivatives}

These phytochemicals have a potency to block the $3 \mathrm{a}$ channel proteins of coronaviruses. The $\operatorname{Yxx} \Phi$ domain of $3 \mathrm{a}$ channel is a protein internalization signal which is involved in clathrin-mediated endocytosis, therefore its involved in virus cell entry. In a research study, using Xenopus oocyte for heterologous expression and applied voltage-clamp techniques, the glycoside juglanin (carrying an arabinose residue) was found as the most effective kaempferol derivatives with an $\mathrm{IC}_{50}$ value of $2.3 \mu \mathrm{M}$ for Inhibition of the 3a-mediated current ${ }^{156}$ (Table 4).

\section{Artesunate}

Bioingredients of Artemisia annua can play potential protective roles against infections by viruses, specifically HSV-1, HBV, $\mathrm{HCV}$, bovine viral diarrhea virus, and Epstein-Barr virus. It was demonstrated that 10 days administration of artesunate (a semi-synthetic derivative of artemisinin used to treat malaria) at $600 \mathrm{nM}$ inhibited HIV-1 replication ${ }^{157}$ (Table 4).

\section{Saikosaponins}

Among saikosaponins (A, B2, C, and D) tested on coronavirus 229E in human fetal lung fibroblasts, saikosaponin B2 demonstrated a potent anticoronaviral activity at a concentration of $25 \mathrm{mmol} / \mathrm{L}$. Although, the mode of action of this compound possibly involved interference in the early stage of viral replication such as absorption and penetration of the virus ${ }^{158}$ (Table 4).

\section{Tellimagrandin}

Initially, the interaction between the HIV envelope glycoprotein gp120 and the cell membrane protein CD4 results in virus-cell fusion. Out of isolated compounds from Eugenia caryophyllata, tellimagrandin significantly inhibited the viruscell fusion and syncytia formation in HIV-1 with an $\mathrm{IC}_{50}$ value of $16.12 \pm 1.98 \mathrm{mg} / \mathrm{ml}^{159}$ (Table 4 ).

\section{Ginkgolic acid}

In Jurkat cells, ginkgolic acid $(31.2 \mu \mathrm{g} / \mathrm{ml})$ isolated from Ginkgo leaves, inhibited the HIV protease activity by $60 \%$ in a dose-dependent manner. Moreover, ginkgolic acid treatment (50 and $100 \mu \mathrm{g} / \mathrm{ml}$ ) effectively inhibited the HIV infection at day 7 dose-dependently ${ }^{93}$ (Table 4 ).

\section{Globoidnan A}

It was reported that Globoidnan A, a lignan obtainable from Eucalyptus globoidea, can interfere with HIV-1 integrase activity. This compound was found to inhibit the combined 3' processing and strand transfer activity of HIV integrase with an $\mathrm{IC}_{50}=0.64 \mu \mathrm{M}^{160}$ (Table 4).

\section{Antiviral herbal medicine formulations KangBingDu}

KangBingDu $(\mathrm{KBD})$ is a Chinese traditional medicinal formula in form of a classic oral liquid that has been modified based on the traditional Chinese "BaiHutang" and "QingWenBaiDuYin" medicine formulations. KBD is often used to improve the clinical symptoms of viral diseases, especially the influenza virus. KBD is composed of Radix isatidis, Rhizoma phragmitis, Radix rehmanniae, Radix curcumae, Rhizoma anemarrhenae, Rhizoma acori tatarinowii, Herba pogostemonis, Fructus forsythiae and Gypsum fibrosum. KBD significantly reduced the sensitivity of male Kunming mice to influenza viruses, which is evidenced by reduced mortality, decreased inflammation, and inhibited viral replication in the pulmonary system. In A549 cells, administration of KBD increased the protein expression of MAVS (mitochondrial antiviral signaling protein) and the levels of IFN- $\beta$ protein and interferon-induced transmembrane-3 protein, resulting in inhibition of viral infection. It was shown that $(R$, S) -Goitrine, Mangiferine, Forsythine, and Forsythoside A were other active ingredients of KBD against the influenza virus. The mitochondrial antiviral signaling pathway was introduced as the primary mechanism of action of KBD. ${ }^{161}$

\section{Maxingshigan-yinqiaosan}

In a prospective RCT, the efficacy and safety of Oseltamivir and a traditional Chinese mixture named "MaxingshiganYinqiaosan" in treatment of uncomplicated influenza H1N1 subtype were compared. Maxingshigan-yinqiaosan consisted of 12 herbs: Zhimahuang (honey-fried Herba Ephedrae); Zhimu (Rhizoma Anemarrhenae); Qinghao (Herba Artemisiae Annuae); Shigao (Gypsum Fibrosum); Yinhua (Flos Lonicerae Japonicae); Huangqin (Radix Scutellariae); Chaoxingren (stir-baked Semen Armeniacae Amarum); Lianqiao (Fructus Forsythiae); Bohe (Fructus Forsythiae); Zhebeimu (Bulbus Fritillariae Thunbergii); Niubangzi (Fructus Arctii Tosum); and Gancao (Radix Et Rhizoma Glycyrrhizae). Clinical interventions and control were given for 5 days with Oseltamivir, 75 mg twice daily; Maxingshigan-yinqiaosan, $200 \mathrm{~mL} 4$ times daily. Oseltamivir and Maxingshigan-yinqiaosan, alone or together, reduced time of fever resolution in patients with H1N1 influenza. ${ }^{162}$ 


\section{Sheng Jiang San}

Sheng Jiang San (SJS) is a Chinese multi-herbal formulation made of four herbs consist of Rhei Radix et Rhizoma, Bombyx Batryticatus, Cicadae Periostracum, and Curcumae Longae Rhizoma. The inhibitory effect of SJS against different strains of influenza virus A/WSN/33 (H1N1) on MDCK cells was examined. The $\mathrm{IC}_{50}$ of SJS was lower than $35 \mu \mathrm{g} / \mathrm{ml}$ against H1N1. SJS at $2 \mathrm{mg} / \mathrm{ml}$ inhibited the NA activity up to $80 \%$. This enzyme cleaves terminal neuraminic acid residues of glycan structures on the surface of the infected cell, thereby facilitating the release and spread of viruses progeny to reach the surrounding uninfected cells. The $\mathrm{IC}_{50}$ of Oseltamivir acid was $250 \mu \mathrm{M}$ against Neuraminidase. To evaluate the efficacy of SJS in the influenza virus, infected BALB/c mice were employed as in vivo model. Oral administration of $1 \mathrm{~g} / \mathrm{kg} /$ day of SJS for 7 days, exhibited $50 \%$ protection of infected mice from $\mathrm{H} 1 \mathrm{~N} 1$ symptoms. SJS also significantly down-regulated tumor necrosis factor (TNF- $\alpha$ ) and up-regulated IL-2 of influenza virusinduced mice. ${ }^{163}$

\section{Lianhuaqingwen}

Lianhuaqingwen (LH) is another Chinese plant medicine composed of 13 herbs with positive impact on SARS-CoV-2 by inhibiting viral replication. A research study revealed that LH significantly inhibited SARS-CoV-2 replication in Vero E6 cells $(600 \mu \mathrm{g} / \mathrm{mL})$ and markedly reduced mRNA transcription of pro-inflammatory cytokines (TNF- $\alpha$, IL-6, CCL-2/MCP-1, and CXCL-10/IP-10). ${ }^{164}$ In addition, LH in the form of capsule ( 4 capsules, thrice daily for 14 days) in patients who were suffering Covid-19 conferred therapeutic effects by improving the recovery rate of symptoms, shortening recovery time, and improving the recovery of chest radiologic abnormalities. ${ }^{165}$

\section{San Wu Huangqin Decoction}

San Wu Huangqin Decoction (SWHD) is a Chinese compound formulation consists of Sophora flavescens, Scutellaria baicalensis, and Rehmannia glutinosa. This herbal formulation could effectively inhibit the influenza A/PR/8/34 (H1N1) virus at all steps of virus replication in vitro. The RNA expression of four H1N1 target viral proteins (hemagglutinin, NA, NP nucleoprotein, and matrix-2) was significantly down-regulated in MDCK cells. In vivo, SWHD at 23.40 and $11.70 \mathrm{~g} / \mathrm{kg}$ significantly attenuated clinical symptoms, reduced mortality, and increased the survival time of infected animals. SWHD mediated the pulmonary index, viral titer, pathological changes in lung tissue, and expression of the main IFV proteins. ${ }^{166}$

\section{Kabasura Kudineer}

Cresset Flare is a software that used for molecular docking studies against the spike protein SARS-CoV-2. In silico molecular docking assay, examining pharmacokinetics parameters, have shown that six plant species in Kabasura Kudineer formula (Sida acuta, Adhatoda vasica, Andrographis paniculata, Tinospora Cordifolia, Costus speciosus, Plectranthus ambonicus) have potential to directly suppress the SARS-CoV-2 spike protein. ${ }^{167}$

\section{Poly-herbal gel}

The anti-HIV activity of an aqueous gel formula containing ethanolic extract of the heartwood of Acacia catechu, leaves of Lagerstroemia speciosa, and fruits of Aegle marmelos,
Phyllanthus emblica, and Terminalia chebula was examined against CXCR4 tropic and CCR5 tropic viruses. The gel inhibited viral activity with $\mathrm{IC}_{50}$ values of $58.17 \pm 4.4$ and $63.54 \pm$ $6.8 \mu \mathrm{g} / \mathrm{ml}$ for CXCR4 and CCR5, respectively. CXCR4 and CCR 5 are two of several chemokine receptors used by the HIV to infect T CD4+ lymphocytes. Furthermore, this gel could inhibit three key enzymes of the HIV-1 reverse transcriptase, protease, and integrase enzymes significantly. ${ }^{168}$

\section{Qing Fei Pai Du Tang}

Qing Fei Pai Du Tang (QFPDT) is a Chinese medicinal preparation consisting of 21 plants derivation of 5 conventional formula. Some studies have reported the QFPDT inhibitory effect of QFPDT on COVID-19. By several mechanisms, QFPDT could prevent the progression of mild COVID-19 cases and shorten the average duration of symptoms and hospitalization. Necessary scientific studies, supported by network pharmacology, reviewed the possible therapeutic targets of QFPDT and its constituents, including Ephedra sinica, Bupleurum chinense, Pogostemon cablin, Cinnamomum cassia, and Scutellaria baicalensis. Their findings indicated that main herbs of QFPDT have antiviral effects via different mechanisms including direct effect on virus replication and autophagy; regulation of host pathways like Toll-like receptors, RIG-1-like helicases, AMPactivated protein kinase, phosphatidyl inositol-3-kinase/ protein kinase B or extracellular regulated kinase 1/2/mitogen-activated protein kinase signal pathways; elevation of the human defense system via $\mathrm{T}$ and $\mathrm{B}$ cell functions, and free radical scavenging activities by enhancing antioxidant enzymes. QFPDT also modulated inflammation conditions through suppression of inflammatory-related genes, signal pathways and cytokines. ${ }^{169}$

\section{Chai-Ling}

Chai-Ling decoction (CLD), derived from a modification of two decoctions, include Xiao-Chai-Hu $(\mathrm{XCH})$ and Wu-LingSan (WLS) decoction, has been used to treat early-stage of COVID-19. The possible mechanisms of CLD in COVID-19 were preliminarily investigated, relying on network pharmacology and molecular docking method. CLD might reduce the inflammatory response and improve lung damages of COVID19 through interleukin 17 signaling, T helper cell 17 differentiation, tumor necrosis factor signaling, and hypoxia-inducible factor-1 signaling. Besides, molecular docking assay indicated that beta-sitosterol, kaempferol, and stigmasterol were the primary three components in CLD with the highest affinity to SARS-CoV-2 and ACE2. ${ }^{170}$

\section{San Yao San}

San Yao San Fang (SYSF) was shown effective in patients with COVID-19. The synergy of SYSF and Western interventions improved the recovery rate of COVID-19 symptoms such as fever, cough, and fatigue, and other symptoms such as headache, gastrointestinal symptoms, myalgia, dyspnoea, and chest tightness. ${ }^{171}$

\section{Conclusion}

Throughout history, humans have been dependent on plant/ natural sources for the treatment of various infections. Over the last few decades, hundreds of plant and herb species were shown to have potential antiviral activities, which 
were attributed to a variety of active phytochemicals including flavonoids, terpenoids, lignans, sulphides, polyphenolics, coumarins, saponins, furyl compounds, alkaloids, polyines, thiophenes, proteins, peptides, and some essential oils. Plant extracts or substances derived from plants possess their antiviral effects through inhibition of viral replication and by deterring the activity of viral reproduction or interacting with vital viral proteins that are associated with virulence. ${ }^{172}$ Their ability to act as bioreactors and production of vaccines under plant platforms are another advantage of plant systems to induce mucosal or long-term immunity against viral infection. Very recently, it was proposed that highly polar glycosylated compounds and polyphenols are more effective antiviral substances, particularly when being administered orally. ${ }^{13}$ In our study, we gathered information about plant extracts, essential oils, and phytochemicals that are favorable for life-threatening coronaviruses diseases and can be potential candidates for further development of antivirals. We found those plant families, including Lamiaceae, Asteraceae, and Myrtaceae contain the highest number of species with anti-coronaviruses activities, respectively. It can be suggested that the combination of these antiviral ingredients with each other, any synthetic compound, or already FDA-approved drugs or inhibitors can be a novel approach for antiviral therapies. Evaluation of efficacy and adverse effects of herbal medicines for the treatment of viral infection is warranted. Recent findings exhibited that a combination of herbal therapy with modern medicines significantly improved the total effective rate and syndrome score of cough, fever, dry, and sore throat, and fatigue in COVID-19 patients, signifying the advantage of herbal therapy for viral infections. ${ }^{173}$

\section{Conflict of Interest}

\author{
None
}

\section{References}

1. Sinkovics J, Horvath J, Horak A. The origin and evolution of viruses (a review). Acta Microbiol Immunol Hung. 1998;45(3-4):349-90.

2. Woolhouse M, Scott F, Hudson Z, Howey R, Chase-Topping MJPTotRSBBS. Human viruses: discovery and emergence. 2012:367(1604):2864-71.

3. Lodish H, Berk A, Zipursky SL, Matsudaira P, Baltimore D, Darnell J. Viruses: Structure, function, and uses. Molecular Cell Biology 4th edition:WH Freeman; 2000.

4. Moss JAJRt. HIV/AIDS Review. 2013;84(3):247-67.

5. Van BM, Debyser ZJAr. HIV-1 integration: an interplay between HIV-1 integrase, cellular and viral proteins. 2005;7(1):26-43.

6. Kilcher S, Mercer JJV. DNA virus uncoating. 2015;479:578-90.

7. Hagan MFJAicp. Modeling viral capsid assembly. 2014;155:1.

8. Lindenbach BD. Virion assembly and release. Hepatitis C Virus: From Molecular Virology to Antiviral Therapy: Springer; 2013. p. 199-218.

9. Kraemer M, Cummings D, Funk S, Reiner R, Faria N, Pybus O, et al. Reconstruction and prediction of viral disease epidemics. Epidemiol Infect. 2019;147.

10. Walls AC, Park Y-J, Tortorici MA, Wall A, McGuire AT, Veesler D. Structure, Function, and Antigenicity of the SARS-CoV-2 Spike Glycoprotein. Cell. 2020;181(2):281-92.e6

11. Nascimento Junior JAC, Santos AM, Quintans-Júnior $L$, Walker CIB, Borges LP, Serafini MR. SARS, MERS and SARS-CoV-2 (COVID-19) treatment: a patent review. Expert Opinion on Therapeutic Patents. 2020(just-accepted).

12. Lu H. Drug treatment options for the 2019-new coronavirus (2019-nCoV). Biosci Trends. 2020;14(1):69-71.

13. Islam MT, Sarkar C, El-Kersh DM, Jamaddar S, Uddin SJ, Shilpi JA, et al. Natural products and their derivatives against coronavirus: A review of the non-clinical and pre-clinical data. Phytother Res.

14. Mani JS, Johnson JB, Steel JC, Broszczak DA, Neilsen PM, Walsh KB, et al. Natural product-derived phytochemicals as potential agents against coronaviruses: A review. Virus Res. 2020;284:197989.

15. Richman DD, Whitley RJ, Hayden FG. Clinical virology: John Wiley \& Sons; 2016

16. Fields BN, Knipe DM, Howley PM, Everiss KD, Kung H-J. Fundamental virology: Lippincott-Raven Philadelphia^ ePA PA; 1996.

17. Modrow S, Falke D, Truyen U, Schätzl H. Molecular virology: Springer Berlin Heidelberg; 2013.

18. Tsurumi T, Fujita M, Kudoh A. Latent and lytic Epstein-Barr virus replication strategies. Rev Med Virol. 2005;15(1):3-15.

19. Kim K-H, Bae J-W. Amplification methods bias metagenomic libraries of uncultured single-stranded and double-stranded DNA viruses. Appl Environ Microbiol. 2011;77(21):7663-8.

20. Weitzman MD, Fradet-Turcotte A. Virus DNA Replication and the Host DNA Damage Response. Annu Rev Virol. 2018;5(1):141-64.

21. Charman M, Weitzman MD. Replication Compartments of DNA Viruses in the Nucleus: Location, Location, Location. Viruses. 2020;12(2):151.

22. Tattersall P, Cotmore SF. Parvoviruses. e LS. 2001.
23. Murphy F. Virus taxonomy; classification and nomenclature of viruses; 6th report of the International Committee on Taxonomy of Viruses. Arch Virol Suppl. 1995;10:415-33.

24. Palese P, Zheng H, Engelhardt OG, Pleschka S, García-Sastre A. Negativestrand RNA viruses: genetic engineering and applications. Proc Natl Acad Sci. 1996:93(21):11354-8

25. García-Sastre A. Negative-strand RNA viruses: applications to biotechnology. Trends Biotechnol. 1998;16(5):230-5.

26. Zarbl H, Millward S. The reovirus multiplication cycle. The Reoviridae: Springer; 1983. p. 107-96.

27. Murray PR, Rosenthal KS, Pfaller MA. Medical microbiology: Elsevier Health Sciences; 2015

28. Libonati M, Carsana A, Furia A. Double-stranded RNA. Mol Cell Biochem. 1980;31(1):147-64.

29. Coffin JM. Structure and Classification of Retroviruses. In: Levy JA, editor. The Retroviridae. Boston, MA: Springer US; 1992. p. 19-49.

30. Stocking C, Kozak C. Endogenous retroviruses. Cell Mol Life Sci. 2008;65(21):3383-98.

31. Gorbalenya AE. Severe acute respiratory syndrome-related coronavirus-The species and its viruses, a statement of the Coronavirus Study Group. BioRxiv. 2020.

32. Wang C, Horby PW, Hayden FG, Gao GF. A novel coronavirus outbreak of global health concern. The Lancet. 2020;395(10223):470-3.

33. Kristoffersen AW, Nordbø SA, Rognlien A-GW, Christensen A, Døllner H. Coronavirus causes lower respiratory tract infections less frequently than RSV in hospitalized Norwegian children. Ped Infect Dis J. 2011;30(4): 279-83.

34. Stewart JN, Mounir S, Talbot PJ. Human coronavirus gene expression in the brains of multiple sclerosis patients. Virology. 1992;191(1):502-5.

35. Lai MM. Coronaviridae: the viruses and their replication 2001

36. Wang L-F, Shi Z, Zhang S, Field H, Daszak P, Eaton BT. Review of bats and SARS. Emerg Infect Dis. 2006;12(12):1834.

37. Cui J, Li F, Shi Z-L. Origin and evolution of pathogenic coronaviruses. Nat Rev Microbiol. 2019;17(3):181-92.

38. Cauchemez S, Van Kerkhove M, Riley S, Donnelly C, Fraser C, Ferguson N. Transmission scenarios for Middle East Respiratory Syndrome Coronavirus (MERS-CoV) and how to tell them apart. Euro Surveill Bull Eur sur les maladies transmissibles Eur Commun Dis Bull. 2013;18(24).

39. Andersen KG, Rambaut A, Lipkin WI, Holmes EC, Garry RF. The proximal origin of SARS-CoV-2. Nat Med. 2020;26(4):450-2.

40. Brian D, Baric R. Coronavirus genome structure and replication. Coronavirus replication and reverse genetics: Springer; 2005. p. 1-30.

41. Holmes KV. CORONAVIRUSES (CORONAVIRIDAE). Encyclopedia of Virology. 1999:291-8.

42. Tan Y-J, Lim SG, Hong W. Characterization of viral proteins encoded by the SARS-coronavirus genome. Antiviral Res. 2005;65(2):69-78. 
43. Hoffmann M, Kleine-Weber H, Schroeder S, Krüger N, Herrler T, Erichsen S, et al. SARS-CoV-2 cell entry depends on ACE2 and TMPRSS2 and is blocked by a clinically proven protease inhibitor. Cell. 2020.

44. Guo Y-R, Cao Q-D, Hong Z-S, Tan Y-Y, Chen S-D, Jin H-J, et al. The origin, transmission and clinical therapies on coronavirus disease 2019 (COVID-19) outbreak-an update on the status. Military Med Res. 2020;7(1):1-10.

45. Walls AC, Park Y-J, Tortorici MA, Wall A, McGuire AT, Veesler D. Structure, function, and antigenicity of the SARS-CoV-2 spike glycoprotein. Cell. 2020.

46. Sola I, Almazan F, Zuniga S, Enjuanes L. Continuous and discontinuous RNA synthesis in coronaviruses. Annu Rev Virol. 2015;2:265-88.

47. Wu H-Y, Guy JS, Yoo D, Vlasak R, Urbach E, Brian DA. Common RNA replication signals exist among group 2 coronaviruses: evidence for in vivo recombination between animal and human coronavius molecules. Virology. 2003;315(1):174-83.

48. Hussain S, Chen Y, Yang Y, Xu J, Peng Y, Wu Y, et al. Identification of novel subgenomic RNAs and noncanonical transcription initiation signals of severe acute respiratory syndrome coronavirus. J Virol. 2005;79(9):5288-95.

49. Qinfen $Z$, Jinming $C$, Xiaojun $H$, Huanying $Z$, Jicheng $H$, Ling $F$, et al. The life cycle of SARS coronavirus in Vero E6 cells. J Med Virol. 2004;73(3):332-7.

50. van Boheemen S, de Graaf M, Lauber C, Bestebroer TM, Raj VS, Zak AM, et al. Genomic characterization of a newly discovered coronavirus associated with acute respiratory distress syndrome in humans. MBio. 2012;3(6):e00473-12.

51. Baba M, Nakajima M, Schols D, Pauwels R, Balzarini J, De Clerca EJAr. Pentosan polysulfate, a sulfated oligosaccharide, is a potent and selective anti-HIV agent in vitro. 1988;9(6):335-43.

52. Baba M, Snoeck R, Pauwels R, De Clercq EJAa, chemotherapy. Sulfated polysaccharides are potent and selective inhibitors of various enveloped viruses, including herpes simplex virus, cytomegalovirus, vesicular stomatitis virus, and human immunodeficiency virus. 1988;32(11):1742-5.

53. Pluymers W, Neamati N, Pannecouque C, Fikkert V, Marchand C, Burke TR, et al. Viral entry as the primary target for the anti-HIV activity of chicoric acid and its tetra-acetyl esters. 2000;58(3):641-8.

54. Witvrouw M, Fikkert V, Pluymers W, Matthews B, Mardel K, Schols D, et al. Polyanionic (ie, polysulfonate) dendrimers can inhibit the replication of human immunodeficiency virus by interfering with both virus adsorption and later steps (reverse transcriptase/integrase) in the virus replicative cycle. 2000:58(5):1100-8.

55. Baranova E, Shastina N, Shvets VJRJoBC. Polyanionic inhibitors of HIV adsorption. 2011;37(5):527.

56. Andrei G, De Clercq E, Snoeck R. Viral DNA polymerase inhibitors. Vira genome replication: Springer; 2009. p. 481-526.

57. McGuigan C, Barucki H, Blewett S, Carangio A, Erichsen JT, Andrei G, et al. Highly potent and selective inhibition of varicella-zoster virus by bicyclic furopyrimidine nucleosides bearing an aryl side chain. 2000;43(26):4993-7

58. Wang J, Froeyen M, Hendrix C, Andrei G, Snoeck R, De Clercq E, et al. The cyclohexene ring system as a furanose mimic: synthesis and antiviral activity of both enantiomers of cyclohexenylguanine. 2000:43(4):736-45.

59. Verweij-van Wissen C, Aarnoutse R, Burger DJJocB. Simultaneous determination of the HIV nucleoside analogue reverse transcriptase inhibitors lamivudine, didanosine, stavudine, zidovudine and abacavi in human plasma by reversed phase high performance liquid chromatography. 2005;816(1-2):121-9.

60. Richman DDJAt. Antiretroviral activity of emtricitabine, a potent nucleoside reverse transcriptase inhibitor. 2001;6(2):83-8.

61. Das K, Clark AD, Lewi PJ, Heeres J, De Jonge MR, Koymans LM, et al. Roles of conformational and positional adaptability in structure-based design of TMC125-R165335 (etravirine) and related non-nucleoside reverse transcriptase inhibitors that are highly potent and effective against wildtype and drug-resistant HIV-1 variants. 2004;47(10):2550-60.

62. Pauwels RJCOiP. New non-nucleoside reverse transcriptase inhibitors (NNRTIs) in development for the treatment of HIV infections. 2004;4(5): 437-46.

63. De Clerca EJC, biodiversity. Non-nucleoside reverse transcriptase inhibitors (NNRTIs): past, present, and future. 2004;1(1):44-64.

64. Donzella GA, Schols D, Lin SW, Esté JA, Nagashima KA, Maddon PJ, et al. AMD3100, a small molecule inhibitor of HIV-1 entry via the CXCR4 Coreceptor. 1998:4(1):72-7.

65. Ding X, Zhang X, Chong H, Zhu Y, Wei H, Wu X, et al. Enfuvirtide (T20)-based lipopeptide is a potent HIV-1 cell fusion inhibitor: implications for viral entry and inhibition. 2017:91(18):e00831-17.

66. Eggink D, Berkhout B, W Sanders RJCpd. Inhibition of HIV-1 by fusion inhibitors. 2010;16(33):3716-28.
67. De Clercq E, Holý AJNRDD. Acyclic nucleoside phosphonates: a key class of antiviral drugs. 2005:4(11):928-40.

68. De Clercq EJBp. Acyclic nucleoside phosphonates: past, present and future: bridging chemistry to HIV, HBV, HCV, HPV, adeno-, herpes-, and poxvirus infections: the phosphonate bridge. 2007;73(7):911-22.

69. De Clercq EJCmr. Clinical potential of the acyclic nucleoside phosphonates cidofovir, adefovir, and tenofovir in treatment of DNA virus and retrovirus infections. 2003;16(4):569-96

70. Anderson J, Schiffer C, Lee S-K, Swanstrom R. Viral protease inhibitors Antiviral strategies: Springer; 2009. p. 85-110

71. Piliero PJJEooid. Atazanavir: a novel HIV-1 protease inhibitor. 2002;11(9):1295-301.

72. Chrusciel RA, Strohbach JWJCtimc. Non-peptidic HIV protease inhibitors 2004:4(10):1097-114.

73. Vergani B, Rusconi SJDiR. Tipranavir in the protease inhibitors arena. 2011:11(4):291-3

74. Zalman L, Brothers M, Dragovich P, Zhou R, Prins T, Worland S, et al. Inhibition of human rhinovirus-induced cytokine production by AG7088, a human rhinovirus 3C protease inhibitor. 2000;44(5):1236-41.

75. Basler CF, Krogan NJ, Leung DW, Amarasinghe GKJAr. Virus and host interactions critical for filoviral RNA synthesis as therapeutic targets. 2019:162:90-100

76. Gubareva LV, Kaiser L, Hayden FGJTL. Influenza virus neuraminidase inhibitors. 2000;355(9206):827-35.

77. McNicholl IR, McNicholl JJJAoP. Neuraminidase inhibitors: zanamivir and oseltamivir. 2001;35(1):57-70

78. Burnham AJ, Baranovich T, Govorkova EAJAr. Neuraminidase inhibitors for influenza B virus infection: efficacy and resistance. 2013;100(2):520-34.

79. Babu YS, Chand P, Bantia S, Kotian P, Dehghani A, El-Kattan Y, et al. BCX1812 (RWJ-270201): discovery of a novel, highly potent, orally active, and selective influenza neuraminidase inhibitor through structure-based drug design. 2000;43(19):3482-6.

80. Markland W, McQuaid T, Jain J, Kwong AJAa, chemotherapy. Broadspectrum antiviral activity of the IMP dehydrogenase inhibitor VX-497: a comparison with ribavirin and demonstration of antiviral additivity with alpha interferon. 2000:44(4):859-66.

81. Parker WBJVr. Metabolism and antiviral activity of ribavirin. 2005;107(2): 165-71.

82. Gish RGJJoAC. Treating HCV with ribavirin analogues and ribavirin-like molecules. 2006:57(1):8-13

83. Huggins J, Zhang Z-X, Bray MJTJoid. Antiviral drug therapy of filovirus infections: S-adenosylhomocysteine hydrolase inhibitors inhibit Ebola virus in vitro and in a lethal mouse model. 1999;179(Supplement_1):S240-S7.

84. Picazo E, Giordanetto FJDdt. Small molecule inhibitors of ebola virus infection. 2015:20(2):277-86

85. Markland W, McQuaid T, Jain J, Kwong A. Broad-spectrum antiviral activity of the IMP dehydrogenase inhibitor VX-497: a comparison with ribavirin and demonstration of antiviral additivity with alpha interferon. Antimicrob Agents Chemother. 2000:44(4):859-66.

86. Parker WB. Metabolism and antiviral activity of ribavirin. Virus Res. 2005;107(2):165-71.

87. Dimitrov DS. Virus entry: molecular mechanisms and biomedical applications. Nat Re Microbiol. 2004;2(2):109-22.

88. Gescher K, Kühn J, Hafezi W, Louis A, Derksen A, Deters A, et al. Inhibition of viral adsorption and penetration by an aqueous extract from Rhododendron ferrugineum $L$. as antiviral principle against herpes simplex virus type-1. Fitoterapia. 2011;82(3):408-13

89. Tao YJ, Ye Q. RNA virus replication complexes. PLoS Pathogens. 2010;6(7)

90. Chin LW, Cheng Y-W, Lin S-S, Lai Y-Y, Lin L-Y, Chou M-Y, et al. Anti-herpes simplex virus effects of berberine from Coptidis rhizoma, a major component of a Chinese herbal medicine, Ching-Wei-San. Arch Virol. 2010;155(12):1933-41

91. Flexner C. HIV-protease inhibitors. New Engl J Med. 1998;338(18):1281-93.

92. Huff JR. HIV protease: a novel chemotherapeutic target for AIDS. J Med Chem. 1991:34(8):2305-14.

93. Lü J-M, Yan S, Jamaluddin S, Weakley SM, Liang Z, Siwak EB, et al. Ginkgolic acid inhibits HIV protease activity and HIV infection in vitro. Med Sci Monitor Int Med J Exp Clin Res. 2012;18(8):BR293.

94. Pommier Y, Johnson AA, Marchand C. Integrase inhibitors to treat HIV/AIDS. Nat Rev Drug Discov. 2005;4(3):236-48.

95. Suedee A, Tewtrakul S, Panichayupakaranant P. Anti-HIV-1 integrase compound from Pometia pinnata leaves. Pharm Biol. 2013:51(10):1256-61.

96. Zhao Q, Chen X-Y, Martin C. Scutellaria baicalensis, the golden herb from the garden of Chinese medicinal plants. Sci Bull. 2016;61(18):1391-8. 
97. Gubareva LV, Kaiser L, Hayden FG. Influenza virus neuraminidase inhibitors. The Lancet. 2000;355(9206):827-35.

98. McAuley J, Gilbertson B, Trifkovic S, Brown LE, McKimm-Breschkin J. Influenza virus neuraminidase structure and functions. Front Microbiol. 2019;10:39.

99. Xue H, ZHANG D-K, Yu-Ming G, Wu-Wen F, Qin D, ZHANG C-E, et al. Screening and evaluation of commonly-used anti-influenza Chinese herbal medicines based on anti-neuraminidase activity. Chin J Nat Med. 2016;14(10):794-800.

100. Hudak KA, Wang P, TUMER NE. A novel mechanism for inhibition of translation by pokeweed antiviral protein: depurination of the capped RNA template. Rna. 2000;6(3):369-80.

101. Kaur I, Gupta R, Puri M. Ribosome inactivating proteins from plants inhibiting viruses. Virol Sin. 2011;26(6):357-65.

102. Thabti I, Albert Q, Philippot S, Dupire F, Westerhuis B, Fontanay S, et al. Advances on antiviral activity of morus spp. plant extracts: human coronavirus and virus-related respiratory tract infections in the spotlight. Molecules. 2020;25(8):1876.

103. Signer J, Jonsdottir H, Albrich W, Strasser M, Züst R, Ryter S. In vitro antiviral activity of Echinaforce ${ }^{\circledR}$, an Echinacea purpurea preparation, against common cold coronavirus 229E and highly pathogenic MERS-CoV and SARS-CoV. Virology. 2020

104. Ngoutane Mfopa A, Corona A, Eloh K, Tramontano E, Frau A, Boyom FF, et al. Uvaria angolensis as a promising source of inhibitors of HIV-1 RT-associated RNA-dependent DNA polymerase and RNase $\mathrm{H}$ functions. Nat Prod Res. 2018;32(6):640-7.

105. Ulasli M, Gurses SA, Bayraktar R, Yumrutas O, Oztuzcu S, Igci M, et al. The effects of Nigella sativa (Ns), Anthemis hyalina (Ah) and Citrus sinensis (Cs) extracts on the replication of coronavirus and the expression of TRP genes family. Mol Biol Rep. 2014;41(3):1703-11.

106. Notka F, Meier G, Wagner RJAr. Concerted inhibitory activities of Phyllanthus amarus on HIV replication in vitro and ex vivo. 2004:64(2):93-102.

107. Yamai M, Tsumura K, Kimura M, Fukuda S, Murakami T, Kimura YJB, biotechnology ${ }_{\text {, }}$ et al. Antiviral activity of a hot water extract of black soybean against a human respiratory illness virus. 2003;67(5):1071-9.

108. Zakay-Rones Z, Thom E, Wollan T, Wadstein J. Randomized study of the efficacy and safety of oral elderberry extract in the treatment of influenza $A$ and B virus infections. J Int Med Res. 2004;32(2):132-40.

109. Pantev A, Ivancheva S, Staneva L, Serkedjieva JJZfNc. Biologically active constituents of a polyphenol extract from Geranium sanguineum $L$. with anti-influenza activity. 2006;61(7-8):508-16.

110. Huang KL, Lai YK, Lin CC, Chang JM. Inhibition of hepatitis B virus production by Boehmeria nivea root extract in HepG2 2.2.15 cells. World J Gastroenterol. 2006;12(35):5721-5.

111. Chang JS, Liu HW, Wang KC, Chen MC, Chiang LC, Hua YC, et al. Ethanol extract of Polygonum cuspidatum inhibits hepatitis B virus in a stable HBVproducing cell line. Antiviral Res. 2005;66(1):29-34.

112. Felipe AM, Rincao VP, Benati FJ, Linhares RE, Galina KJ, de Toledo CE, et al. Antiviral effect of Guazuma ulmifolia and Stryphnodendron adstringens on poliovirus and bovine herpesvirus. Biol Pharm Bull. 2006;29(6):1092-5.

113. Parida M, Upadhyay C, Pandya G, Jana AJJoe. Inhibitory potential of neem (Azadirachta indica Juss) leaves on dengue virus type-2 replication. 2002;79(2):273-8

114. Micol V, Caturla N, Pérez-Fons L, Más V, Pérez L, Estepa AJAr. The olive leaf extract exhibits antiviral activity against viral haemorrhagic septicaemia rhabdovirus (VHSV). 2005;66(2-3):129-36

115. Lee-Huang S, Zhang L, Huang PL, Chang YT, Huang PL. Anti-HIV activity of olive leaf extract (OLE) and modulation of host cell gene expression by HIV-1 infection and OLE treatment. Biochem Biophys Res Commun. 2003;307(4):1029-37.

116. Mpiana PT, Ngbolua K-T-N, Tshibangu D, Kilembe J, Mwanangombo D, Inkoto C, et al. Aloe vera (L.) Burm. F. as a potential anti-COVID-19 plant: a mini-review of its antiviral activity. 2020

117. Sun Z, Yu C, Wang W, Yu G, Zhang T, Zhang L, et al. Aloe polysaccharides inhibit influenza A virus infection-a promising natural anti-flu drug. Front Microbiol. 2018:9:2338.

118. Reichling J, Schnitzler P, Suschke U, Saller R. Essential oils of aromatic plants with antibacterial, antifungal, antiviral, and cytotoxic properties-an overview. Complement Med Res. 2009;16(2):79-90.

119. Dhifi W, Bellili S, Jazi S, Bahloul N, MnifW. Essential oils' chemical characterization and investigation of some biological activities: a critical review. Medicines. 2016;3(4):25.

120. Loizzo MR, Saab AM, Tundis R, Statti GA, Menichini F, Lampronti I, et al. Phytochemical analysis and in vitro antiviral activities of the essential oils of seven Lebanon species. 2008:5(3):461-70.
121. Wu Q-f, Wang W, Dai X-y, Wang Z-y, Shen Z-h, Ying H-z, et al. Chemical compositions and anti-influenza activities of essential oils from Mosla dianthera. 2012;139(2):668-71.

122. Tseliou M, Pirintsos SA, Lionis C, Castanas E, Sourvinos G. Antiviral effect of an essential oil combination derived from three aromatic plants (Coridothymus capitatus (L.) Rchb. f., Origanum dictamnus L. and Salvia fruticosa Mill.) against viruses causing infections of the upper respiratory tract. J Herbal Med. 2019;17-18:100288.

123. Garozzo A, Timpanaro R, Bisignano B, Furneri P, Bisignano G, Castro AJLiam. In vitro antiviral activity of Melaleuca alternifolia essential oil. 2009;49(6): 806-8

124. Abu-Jafar A, Huleihel MJIJoCV. Antiviral activity of Eucalyptus camaldulensis leaves ethanolic extract on herpes viruses infection. 2017;1:1-9.

125. Adeniyi CBA, Lawal TO, Mahady GBJPb. In vitro susceptibility of Helicobacter pylori to extracts of Eucalyptus camaldulensis and Eucalyptus torelliana. 2009;47(1):99-102.

126. El-Baz FK, Mahmoud K, El-Senousy WM, Darwesh O, El Gohary AJIJPSRR. Antiviral-antimicrobial and schistosomicidal activities of Eucalyptus camaldulensis essential oils. 2015;31(1):262-8

127. Chung MSJFs, biotechnology. Antiviral activities of Artemisia princeps var. orientalis essential oil and its a-thujone against norovirus surrogates. 2017;26(5):1457-61.

128. Sinico C, De Logu A, Lai F, Valenti D, Manconi M, Loy G, et al. Liposomal incorporation of Artemisia arborescens $L$. essential oil and in vitro antiviral activity. 2005;59(1):161-8.

129. Duschatzky CB, Possetto ML, Talarico LB, García CC, Michis F, Almeida NV et al. Evaluation of chemical and antiviral properties of essential oils from South American plants. 2005;16(4):247-51

130. Garcia C, Talarico L, Almeida N, Colombres S, Duschatzky C, Damonte EJPRAIJDtP, et al. Virucidal activity of essential oils from aromatic plants of San Luis, Argentina. 2003;17(9):1073-5.

131. Brochot A, Guilbot A, Haddioui L, Roques CJM. Antibacterial, antifungal, and antiviral effects of three essential oil blends. 2017;6(4):e00459.

132. Astani A, Reichling J, Schnitzler PJPRAIJDtP, Derivatives TEoNP. Comparative study on the antiviral activity of selected monoterpenes derived from essential oils. 2010;24(5):673-9.

133. Astani A, Reichling J, Schnitzler PJE-bc, medicine a. Screening for antiviral activities of isolated compounds from essential oils. 2011;2011.

134. Ibrahim NA, El-Hawary SS, Mohammed M, Farid M, Abdel-Wahed NAM, Ali M, et al. Chemical composition, antiviral against avian influenza (H5N1) virus and antimicrobial activities of the essential oils of the leaves and fruits of Fortunella margarita, lour. swingle, growing in Egypt. J Appl Pharm Sci. 2015:5:006-12.

135. Pourghanbari G, Nili H, Moattari A, Mohammadi A, Iraji A. Antiviral activity of the oseltamivir and Melissa officinalis L. essential oil against avian influenza A virus (H9N2). Virusdisease. 2016;27(2):170-8.

136. Swamy MK, Sinniah UR. A comprehensive review on the phytochemical constituents and pharmacological activities of pogostemon cablin benth.: an aromatic medicinal plant of industrial importance. Molecules. 2015;20(5):8521-47

137. Li YC, Peng SZ, Chen HM, Zhang FX, XU PP, Xie JH, et al. Oral administration of patchouli alcohol isolated from Pogostemonis Herba augments protection against influenza viral infection in mice. Int Immunopharmacol. 2012;12(1):294-301.

138. Wu H, Li B, Wang X, Jin M, Wang G. Inhibitory effect and possible mechanism of action of patchouli alcohol against influenza $A(H 2 N 2)$ virus. Molecules. 2011;16(8):6489-501.

139. Roy S, Chaurvedi P, Chowdhary A. Evaluation of antiviral activity of essential oil of Trachyspermum Ammi against Japanese encephalitis virus. Pharmacognosy Res. 2015;7(3):263-7.

140. Lee-Huang S, Zhang L, Huang PL, Chang Y-T, Huang PLJB, Communications BR. Anti-HIV activity of olive leaf extract (OLE) and modulation of host cell gene expression by HIV-1 infection and OLE treatment. 2003;307(4):1029-37.

141. Cella M, Riva D, Coulombié F, Mersich SJRAdm. Virucidal activity presence in Trichilia glabra leaves. 2004;36(3):136-8.

142. Hayashi K, Imanishi N, Kashiwayama Y, Kawano A, Terasawa K, Shimada Y, et al. Inhibitory effect of cinnamaldehyde, derived from Cinnamomi cortex, on the growth of influenza A/PR/8 virus in vitro and in vivo. Antiviral Res. 2007;74(1):1-8

143. Salem MM, Werbovetz KA. Isoflavonoids and other compounds from Psorothamnus arborescens with antiprotozoal activities. J Nat Prod. 2006;69(1):43-9.

144. Zhou J, Xie G, Yan X. Encyclopedia of traditional Chinese medicines. Isolat Compound AB. 2011:1:455. 
145. Yi L, Li Z, Yuan K, Qu X, Chen J, Wang G, et al. Small molecules blocking the entry of severe acute respiratory syndrome coronavirus into host cells. J Virol. 2004;78(20):11334-9.

146. ul Qamar MT, Alqahtani SM, Alamri MA, Chen L-L. Structural basis of SARSCoV-2 3CLpro and anti-COVID-19 drug discovery from medicinal plants. 2020.

147. Yu M-S, Lee J, Lee JM, Kim Y, Chin Y-W, Jee J-G, et al. Identification of myricetin and scutellarein as novel chemical inhibitors of the SARS coronavirus helicase, nsP13. Bioorg Med Chem Lett. 2012;22(12):4049-54.

148. Li S-y, Chen C, Zhang H-q, Guo H-y, Wang H, Wang L, et al. Identification of natural compounds with antiviral activities against SARS-associated coronavirus. 2005;67(1):18-23

149. Cinatl J, Morgenstern B, Bauer G, Chandra P, Rabenau H, Doerr HJTL. Glycyrrhizin, an active component of liquorice roots, and replication of SARS-associated coronavirus. 2003;361(9374):2045-6.

150. Jo S, Kim H, Kim S, Shin DH, Kim MS. Characteristics of flavonoids as potent MERS-CoV 3C-like protease inhibitors. Chem Biol Drug Design. 2019:94(6):2023-30.

151. Liu H, Ye F, Sun Q, Liang H, Li C, Lu R, et al. Scutellaria baicalensis extract and baicalein inhibit replication of SARS-CoV-2 and its 3C-like protease in vitro. bioRxiv. 2020.

152. Esposito F, Carli I, Del Vecchio C, Xu L, Corona A, Grandi N, et al. Sennoside $A$, derived from the traditional chinese medicine plant Rheum $L$., is a new dual HIV-1 inhibitor effective on HIV-1 replication. Phytomedicine. 2016;23(12):1383-91

153. Yang $C-M$, Cheng H-Y, Lin T-C, Chiang L-C, Lin C-CJJoe. The in vitro activity of geraniin and 1, 3, 4, 6-tetra-O-galloyl- $\beta$-d-glucose isolated from Phyllanthus urinaria against herpes simplex virus type 1 and type 2 infection. 2007:110(3):555-8

154. Sanna C, Rigano D, Cortis P, Corona A, Ballero M, Parolin C, et al. Onopordum illyricum L., a Mediterranean plant, as a source of anti HIV-1 compounds. Plant Biosyst Int J Dealing Aspects Plant Bio. 2018;152(6):1274-81

155. Tsai YC, Lee CL, Yen HR, Chang YS, Lin YP, Huang SH, et al. Antiviral Action of Tryptanthrin Isolated from Strobilanthes cusia Leaf against Human Coronavirus NL63. Biomolecules. 2020;10(3)

156. Schwarz S, Sauter D, Wang K, Zhang R, Sun B, Karioti A, et al. Kaempferol derivatives as antiviral drugs against the 3 a channel protein of coronavirus. Planta Med. 2014;80(2-3):177-82.

157. Haq FU, Roman M, Ahmad K, Rahman SU, Shah SMA, Suleman N, et al. Artemisia annua: Trials are needed for COVID-19. Phytother Res. 2020.

158. Cheng PW, Ng LT, Chiang LC, Lin CC. Antiviral effects of saikosaponins on human coronavirus 229E in vitro. Clin Exp Pharmacol Physiol. 2006;33(7):612-6

159. Kim HJ, Lee JS, Woo ER, Kim MK, Yang BS, Yu YG, et al. Isolation of virus-cell fusion inhibitory components from Eugenia caryophyllata. Planta Med. 2001;67(3):277-9
160. Ovenden SP, Yu J, Wan SS, Sberna G, Tait RM, Rhodes D, et al. Globoidnan A a lignan from Eucalyptus globoidea inhibits HIV integrase. Phytochemistry. 2004;65(24):3255-9

161. Chen H, Jie C, Tang LP, Meng H, Li XB, Li YB, et al. New insights into the effects and mechanism of a classic traditional Chinese medicinal formula on influenza prevention. Phytomed Int J Phytother Phytopharmacol. 2017:27:52-62.

162. Wang C, Cao B, Liu Q-Q, Zou Z-Q, Liang Z-A, Gu L, et al. Oseltamivir compared with the Chinese traditional therapy Maxingshigan-Yinqiaosan in the treatment of H1N1 influenza: a randomized trial. Ann Intern Med. 2011:155(4):217-25.

163. Zhang T, Xiao M, Wong C-K, Mok K-PC, Zhao X, Ti H, et al. Sheng Jiang San, a traditional multi-herb formulation, exerts anti-influenza effects in vitro and in vivo via neuraminidase inhibition and immune regulation. BMC Complement Alternat Med. 2018;18(1):150.

164. Runfeng L, Yunlong $H$, Jicheng H, Weiqi P, Qinhai M, Yongxia S, et al. Lianhuaqingwen exerts anti-viral and anti-inflammatory activity against novel coronavirus (SARS-CoV-2). Pharmacol Res. 2020:156:104761.

165. Hu K, Guan W-j, Bi Y, Zhang W, Li L, Zhang B, et al. Efficacy and safety of Lianhuaqingwen capsules, a repurposed Chinese herb, in patients with coronavirus disease 2019: A multicenter, prospective, randomized controlled trial. Phytomed Int J Phytother Phytopharmacol. 2020:153242.

166. Ma Q, Yu Q, Xing X, Liu S, Shi C, Luo J. San Wu Huangqin Decoction, a Chinese Herbal Formula, Inhibits Influenza a/PR/8/34 (H1N1) Virus Infection In Vitro and In Vivo. Viruses. 2018;10(3).

167. Kiran G, Karthik L, Shree Devi MS, Sathiyarajeswaran P, Kanakavalli K, Kuma KM, et al. In Silico computational screening of Kabasura Kudineer - Official Siddha Formulation and JACOM against SARS-CoV-2 spike protein. J Ayurv Integr Med. 2020

168. Mishra NN, Agarwal A, Moitra T, Polachira SK, Nair R, Gupta SK. Anti-HIV-1 activity and safety profile of a polyherbal gel formulation as a candidate microbicide. J Herb Med. 2019;17-18:100284.

169. Zhong L, Yang W, Lam WC, Bian Z-X, Wong V, Cho S, et al. Potential targets for treatment of coronavirus disease 2019 (COVID-19): a review of Qing-FeiPai-Du-Tang and its major herbs. Am J Chin Med. 2020;48.

170. Yang L, Li Y-T, Miao J, Wang L, Fu H, Li Q, et al. Network pharmacology studies on the effect of Chai-Ling decoction in coronavirus disease 2019. Trad Med Res. 2020;5(3):145-59.

171. Tai ZY, Tay L, Goh RM, Zhou RS, Wong LH, Wong PO. Mixed Chinese herbs and Western medicine for novel coronavirus disease 2019 (COVID-19): a mixed method review. medRxiv. 2020.

172. Jassim SAA, Naji MA. Novel antiviral agents: a medicinal plant perspective. J Appl Microbiol. 2003;95(3):412-27.

173. Ang L, Song E, Lee HW, Lee MS. Herbal medicine for the treatment of coronavirus disease 2019 (COVID-19): a systematic review and meta-analysis of randomized controlled trials. J Clin Med. 2020;9(5):1583. 